\title{
DEAD-Box RNA Helicases in Cell Cycle Control and Clinical Therapy
}

\author{
Lu Zhang ${ }^{1,2}$ and Xiaogang $\mathrm{Li}^{2,3, *}$ \\ 1 Department of Nephrology, Renmin Hospital of Wuhan University, Wuhan 430060, China; \\ zhanglu.1@foxmail.com \\ 2 Department of Internal Medicine, Mayo Clinic, 200 1st Street, SW, Rochester, MN 55905, USA \\ 3 Department of Biochemistry and Molecular Biology, Mayo Clinic, 200 1st Street, SW, \\ Rochester, MN 55905, USA \\ * Correspondence: li.xiaogang@mayo.edu; Tel.: +1-507-266-0110
}

Citation: Zhang, L.; Li, X. DEAD-Box RNA Helicases in Cell Cycle Control and Clinical Therapy. Cells 2021, 10, 1540. https://doi.org/10.3390/ cells10061540

Academic Editors: Ritva Tikkanen and Alexander E. Kalyuzhny

Received: 10 May 2021

Accepted: 15 June 2021

Published: 18 June 2021

Publisher's Note: MDPI stays neutral with regard to jurisdictional claims in published maps and institutional affiliations.

Copyright: (c) 2021 by the authors. Licensee MDPI, Basel, Switzerland. This article is an open access article distributed under the terms and conditions of the Creative Commons Attribution (CC BY) license (https:/ / creativecommons.org/licenses/by/ $4.0 /)$.

\begin{abstract}
Cell cycle is regulated through numerous signaling pathways that determine whether cells will proliferate, remain quiescent, arrest, or undergo apoptosis. Abnormal cell cycle regulation has been linked to many diseases. Thus, there is an urgent need to understand the diverse molecular mechanisms of how the cell cycle is controlled. RNA helicases constitute a large family of proteins with functions in all aspects of RNA metabolism, including unwinding or annealing of RNA molecules to regulate pre-mRNA, rRNA and miRNA processing, clamping protein complexes on RNA, or remodeling ribonucleoprotein complexes, to regulate gene expression. RNA helicases also regulate the activity of specific proteins through direct interaction. Abnormal expression of RNA helicases has been associated with different diseases, including cancer, neurological disorders, aging, and autosomal dominant polycystic kidney disease (ADPKD) via regulation of a diverse range of cellular processes such as cell proliferation, cell cycle arrest, and apoptosis. Recent studies showed that RNA helicases participate in the regulation of the cell cycle progression at each cell cycle phase, including G1-S transition, S phase, G2-M transition, mitosis, and cytokinesis. In this review, we discuss the essential roles and mechanisms of RNA helicases in the regulation of the cell cycle at different phases. For that, RNA helicases provide a rich source of targets for the development of therapeutic or prophylactic drugs. We also discuss the different targeting strategies against RNA helicases, the different types of compounds explored, the proposed inhibitory mechanisms of the compounds on specific RNA helicases, and the therapeutic potential of these compounds in the treatment of various disorders.
\end{abstract}

Keywords: DEAD-box RNA helicases; cell cycle; treatment; DDX5; DDX3

\section{Introduction \\ 1.1. Cell Cycle}

The cell cycle is a series of events that occur in the interphase and mitotic phase (M-phase) [1,2]. The interphase is the longest phase of the cell cycle in which the genetic material gets duplicated and the cell prepares for division. The interphase includes three sub-phases: (1) G1-phase; the first-gap phase. In the G1-phase, cells grow in size, synthesize cell organelles and other proteins, and accumulate sufficient energy to prepare for cell division. (2) S-phase; the synthesis and DNA-replication phase. The centrosome and DNA are duplicated and give rise to the mitotic spindle during this phase. (3) G2-phase; the second gap phase. In the G2 phase, cells accumulate energy and grow further in size. Following the interphase is a period called the mitotic phase (M-phase). The M-phase includes two different critical processes: mitosis and cytokinesis. Mitosis consists of four sub-phases: prophase, metaphase, anaphase, and telophase. The cell divides the nucleus and a complete set of chromosomes into two daughter cells during mitosis. The cytoplasm splits and forms two independent cells in the process of cytokinesis [3,4] (Figure 1). The cell 
cycle is regulated by a series of cell cycle regulatory proteins. Cyclins and cyclin-dependent kinases (CDKs) families are key regulators of cell cycle progression [5]. At least nine CDKs are identified in animal cells, in which CDK1, CDK2, CDK3, and CDK4 are involved in the direct regulation of the cell cycle [6]. In general, CDKs that are active at each stage partner with cyclins to regulate cell cycle progression. CDK1 drives the cell cycle of G2 and M-phase with its partners, cyclin A2 and cyclin B1. CDK2 drives the cell cycle of G1, S, and G2 phases with its partners, cyclin A, cyclin D, and cyclin E. CDK3 drives the cell cycle of G0 phase with its partner, cyclin C. CDK4 and CDK6 drive the cell cycle of G1 phase, with its partners, cyclin D (D1, D2, and D3) and cyclin E (Figure 1).

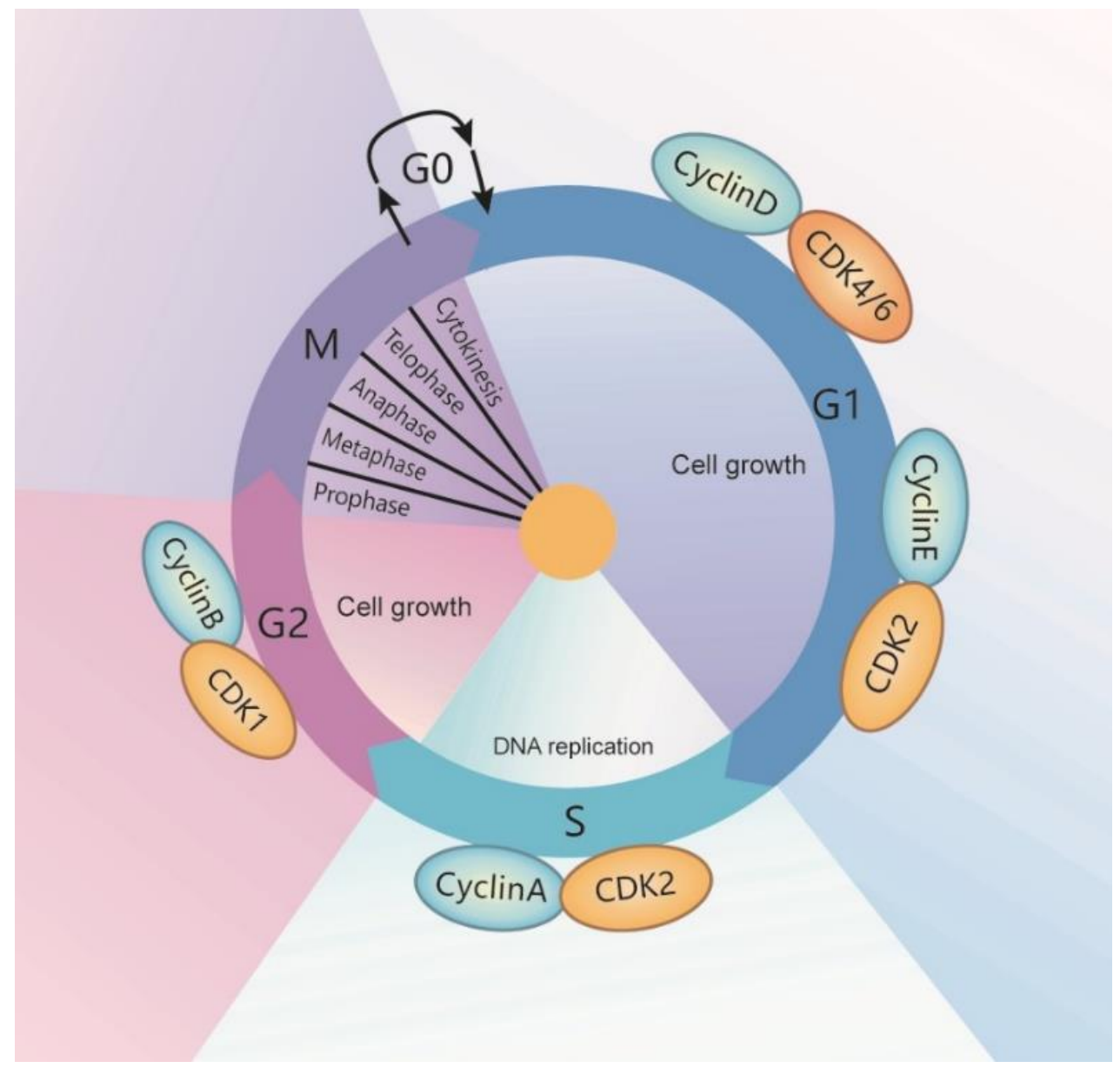

Figure 1. Schematic representation of the cell cycle. The cell cycle is divided into interphase (G1, S, G2) and mitotic phases. Nondividing cells are in G0. Cell cycle progression is controlled by cyclin/cyclin-dependent kinase (CDK) complexes in specific cell cycle phases.

During the cell cycle, there are three checkpoints that occur at the end of G1 and the transition of G2/M, and in metaphase. The G1 checkpoint blocks the entry of the cell cycle into the $S$ phase if a cell does not fulfill all the conditions, which lets the cell try to solve the conditions, or lets the cell enter into the G0 phase. The $\mathrm{G}_{2}$ checkpoint bars the entry of the cell cycle into the mitotic phase if certain conditions are not met, which ensures that all of the genetic material has been replicated and is not damaged. A damaged DNA will halt the cell cycle to let the damaged DNA be repaired. The M checkpoint, also named as the spindle checkpoint, is a point close to the end of the metaphase stage to make sure whether each pair of sister chromatids is correctly anchored to the two spindle microtubules-if not, the cycle will be halted. Recent studies suggest that RNA helicases are involved in these processes. 


\subsection{RNA Helicases}

RNA helicases are ubiquitous, highly conserved enzymes that involve in nearly all aspects of RNA metabolism. RNA helicases use ATP to bind or remodel RNA, RNA secondary structure or ribonucleoprotein (RNP) complexes that are associated with RNA transcription, degradation, translation initiation, mRNA splicing, and ribosome biogenesis [7-9]. RNA helicases are grouped into various superfamilies dependent on the contents of conserved motifs. Most of RNA helicases relate to the superfamily 2 (SF2) of helicases comprising eleven subfamilies, five of which are termed the DExH/D helicases (DEAD-box, RIG-I-like DExH, SKI2-like DExH, viral DExH, and DEAH/RHA) with a conserved motif (Asp-Glu-Ala-Asp/His) [10]. Members of the DEAD-box (DDX) and DExH box families share a similar three-dimensional core structure containing a minimum of 12 conserved amino acid motifs, comprised of two tandemly repeated RecA-like domains [7,9]. The RecA domain 1 includes the ATP binding motifs (Q motif, I motif, and II motif), the ATP hydrolysis motif III, and the RNA-binding motifs (Ia motif and Ib motif) (Figure 2). The RecA domain 2 consists of the RNA-binding motifs (IV and V) and motif VI, which may regulate ATPase and unwinding activities $[9,11]$. Previous studies indicate that motifs Ia and $\mathrm{Ib}$ are structurally similar to motifs IV and $\mathrm{V}$, respectively, which should have similar functions [12]. The $\mathrm{N}$ - and/or $\mathrm{C}$-terminal extensions of most of the RNA helicases are able to interact with specific RNA or protein cofactors. This family of DEAD-box RNA helicases is able to unwind and restructure RNA molecules in an ATPase-dependent manner (Figure 2) [13,14].

\section{RNA helicase core}

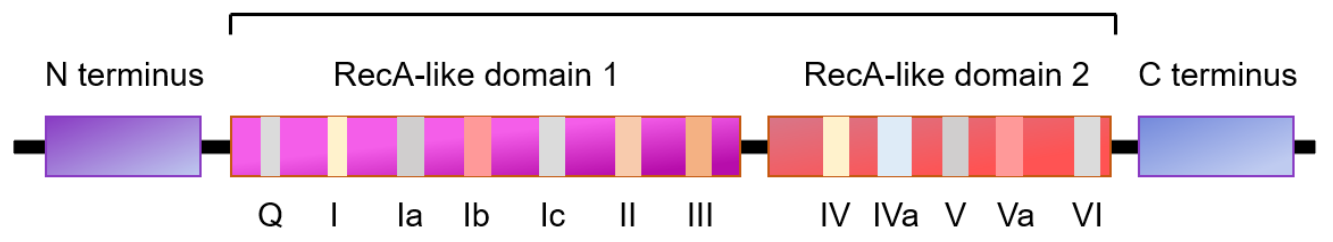

Figure 2. The sequence motifs of DEAD-box RNA helicases family are conserved. The DEAD-box RNA helicases family is characterized by a minimum of 12 conserved domains to form the DEADbox helicase core, which consists of two RecA-related domains. Domain I and II contains 7 and 5 sequence motifs, respectively. The motifs of Q, I, II, and VI function as ATP binding and hydrolysis, and the motifs of Ia, Ib, Ic, IV, IVa, and V function as RNA binding. The motifs III and Va function as coordination between RNA and ATP binding. Domain II includes the DEAD motif (asp-Glu-ala-asp). The DEAD-box RNA helicases usually contain $\mathrm{N}$ and $\mathrm{C}$ terminal extensions, which determine their interaction with specific RNA and/or protein.

RNA helicases play important roles in diverse biological processes. First, RNA helicases can regulate gene expression through catalyzing RNP complex rearrangements at the initiation of gene transcription and then are involved in gene post-transcriptional expression via regulation of ribosome biogenesis, RNA export, translation initiation and termination, and mRNA degradation [13]. Most of the RNA helicases move along a single strand of RNA to unwind secondary structures and displace other bound RNAs or proteins along the way. However, some DEAD-box RNA helicases, such as eIF4A (eukaryotic initiation factor $4 \mathrm{~A}$ ) are able to bind directly to the RNA double-strand and melt it $[13,15]$. Second, RNA helicases can also regulate cap-dependent translation initiation of mRNAs with a complex $5^{\prime}$ UTR structure [16]. For example, eIF4A is required for the translation of oncogenes that contain complex secondary structures in their $5^{\prime}$ untranslated region through unwinding the 5'UTR (e.g., MYC, NOTCH1, MYB, CDK6, MDM2) [16-18]. In eukaryotes, the eIF4F translation initiation complex consists of three subunits: eIF4E, eIF4A, and eIF4G, which recruits the $40 \mathrm{~S}$ ribosomal unit to the $5^{\prime}$ m7G-cap structure of the mRNA. Third, the DEAD-box containing RNA helicases, including DDX1, DDX5, DDX17, DDX20, 
DDX21, and RHA, can function as either transcriptional co-activators or co-repressors via interaction with spliceosome components $[8,13,19]$.

The DEAD-box containing RNA helicases also play important roles in the pathophysiology of viral infection, aging, autosomal dominant polycystic kidney disease (ADPKD), neurological disorders, and cancer. First, the reduction of DDX3 is positively linked with hepatitis virus infection, especially HBV [20]. UAP56 or its paralog URH49 prevents the accumulation of dsRNA during influenza A virus infection via unwinding RNA [21]. Second, RNA helicase DDX5 (also known as p68) is usually downregulated in the aged mouse brain, indicating an association of p68 function with aging [22]. Third, we recently showed that p68 is upregulated in $P k d 1$ mutant renal epithelial cells and tissues to regulate cystic renal epithelial cell proliferation and renal fibrosis through activation of the PKD-associated pathways, including ERK, mTOR, Rb, and TGF- $\beta 1$ [19]. Forth, studies have confirmed that mutation of DDX3 is a significant cause of neurodevelopmental issues, including intellectual disabilities, hypotonia, autism spectrum disorder (ASD), corpus callosum malformations, microcephaly, and seizures [23]. In addition, RNA helicase DDX6 promotes neuronal differentiation by increasing the activity of the microRNA Let-7a [24]. Last, DDX5 has been implicated in several tumors (e.g., NSCLC, breast cancer, gastric cancer, multiple myeloma, glioma) [25-29] through aberrant expression or through the regulation of proliferation, metastasis, and invasion pathways that directly regulate oncogenesis. The precise transition between cell cycle phases is important for development, and the dysregulation of cell cycle results in diverse human diseases, such as promoting oncogenesis [30]. In this review, we will highlight the main functions of RNA helicases in the regulation of cell cycle, and discuss the inhibitors of RNA helicases, including eIF4A, DDX3 and DDX5, as promising therapeutic strategy through regulation of cell cycle [31-34].

\section{The Role of RNA Helicases in Regulation of Cell Cycle Progression}

\subsection{RNA Helicases Regulate G1-S Phase Transition}

In the cell cycle, the G1 phase is the first gap during which the cell prepares for DNA replication. In the G1 phase, the activity of CDKs promotes DNA replication and initiates G1/S phase transition. In general, cyclin D/CDK4/6 complexes play a critical role in the G1 phase; cyclin E/CDK2 complex plays a critical role in the G1 to $S$ transition [35]. In the early $\mathrm{G} 1$ phase, growth factor signaling promotes the synthesis of cyclin $\mathrm{D}$, then induces the formation of cyclin D/CDK4/6 complexes, resulting in the activation of CDKs [36]. Cyclin D/CDK4 and cyclin E/CDK2 complexes sequentially phosphorylate retinoblastoma protein (RB) (inactive form), leading to the release E2F from Rb-E2F complex and the activation of $\mathrm{E} 2 \mathrm{~F}$ [37]. The activated $\mathrm{E} 2 \mathrm{~F}$ then regulates the transcription of genes involved in cell cycle progression, including CDK2, cyclins A and E, and DNA synthesis, to promote G1/S transition [38,39]. During DNA damage, p53 acts as a transcription factor to upregulate the expression of p21, leading to cell cycle arrest in the G1/S phase [40]. Different RNA helicases are involved in transcriptional, translational, and post-translational regulation of the expression of cell cycle regulators.

DDX3/Ded1 is one of the most widely studied DEAD-box RNA helicases. DDX3 regulates RNA metabolism, including transcription, pre-mRNA splicing, RNA export, and translation, which plays a critical role in many biological processes [20]. DDX3 also promotes phase separation when it interacts with ATP [41]. DDX3 also regulates cell apoptosis via the p53 signaling pathway during embryonic development in animal models [42]. Dysregulation of DDX3 plays a critical role in various diseases, including inflammation, viral infection, neurological disorders, and cancer [41,43]. The role of DDX3 in oncogenesis is related to the regulation of cell growth, cell cycle, and cell survival. Increased DDX3 expression promotes cancer cell growth in medulloblastoma, colorectal, breast, prostate, and lung cancer [20,44-46], whereas depletion of DDX3 induces cell cycle arrest in the G1 phase in cancer cells of those cancers (Table 1) [20,31,47-49]. Knockdown of DDX3 also inhibits cell cycle progression by blocking entry into the $S$ phase. Mechanically, DDX3 facilitates translation initiation of the cell cycle regulator cyclin E1 mRNA via its 
$5^{\prime}$ UTR [50]. In addition, DDX3 inhibits the expression of Krüppel-like factor 4 (Klf4) by altering its mRNA splicing, resulting in an upregulation of the expression of CCNA2 and CDK2 [31]. In sum, DDX3 promotes G1/S transition by promoting cyclin E1 translation, suppressing KLF4 expression, and promoting CDK2 expression (Figure 3).

Table 1. RNA Helicases in each Cell Cycle Stage and their Intracellular Localization.

\begin{tabular}{|c|c|c|c|}
\hline Cell Cycle Stage & RNA Helicases & Intracellular Location & Expression \\
\hline \multirow{6}{*}{ G1-S phase transition } & Ded1/DDX3 & $\begin{array}{l}\text { Nuclear speckles and } \\
\text { cytoplasm }\end{array}$ & $\begin{array}{c}\text { Upregulation in medulloblastoma, } \\
\text { colorectal, breast, prostate, and lung } \\
\text { cancer }\end{array}$ \\
\hline & DHX33 & Nucleus and nucleoli & $\begin{array}{l}\text { Upregulation in lung cancers, } \\
\text { hepatocellular carcinoma, lymphoma, } \\
\text { colon cancer, and glioblastoma }\end{array}$ \\
\hline & DHX9 & Nucleus & $\begin{array}{c}\text { Upregulation in cervical cancer, breast } \\
\text { cancer, prostate cancer, colorectal cancer, } \\
\text { hepatocellular carcinoma, and Ewing } \\
\text { sarcoma }\end{array}$ \\
\hline & DDX21 & Nucleus and cytoplasm & $\begin{array}{c}\text { Dysregulation in colon cancer, } \\
\text { lymphomas, neuroblastoma, and breast } \\
\text { cancers }\end{array}$ \\
\hline & eIF4A & Nucleus and cytoplasm & $\begin{array}{l}\text { Dysregulation in pancreatic cancer, breast } \\
\text { cancer, prostate cancer }\end{array}$ \\
\hline & DDX46 & Focal nuclear & $\begin{array}{l}\text { Upregulated in colorectal carcinoma, } \\
\text { esophageal squamous cell carcinoma, } \\
\text { gastric cancer, and osteosarcoma cells }\end{array}$ \\
\hline S phase progression & DDX51 & Predominantly in nuclear & Dysregulation in NSCLC \\
\hline \multirow[t]{2}{*}{ G2-M phase transition } & DDX56 & Nucleolus & $\begin{array}{l}\text { Upregulation of DDX56 in various cancer, } \\
\text { including osteosarcoma, colorectal cancer, } \\
\text { and relates to a poor prognosis }\end{array}$ \\
\hline & DHX33 & Nucleus and nucleoli & See above \\
\hline \multirow{2}{*}{ Mitosis } & UAP56 & Nucleus and cytoplasm & Not clear \\
\hline & URH49 & Nucleus and cytoplasm & Not clear \\
\hline \multirow{3}{*}{ Cytokinesis } & UAP56 & Nucleus and cytoplasm & Not clear \\
\hline & URH49 & Nucleus and cytoplasm & Not clear \\
\hline & DDX6 & Nucleus and cytoplasm & $\begin{array}{l}\text { colorectal cancer and hepatocellular } \\
\text { carcinoma }\end{array}$ \\
\hline \multirow{3}{*}{$\begin{array}{l}\text { Regulate the expression of } \\
\text { p21(WAF1/CIP1) }\end{array}$} & DDX41 & Nucleus and cytoplasm & $\begin{array}{l}\text { DDX41 mutant leads to anemia and acute } \\
\text { myeloid leukemia. DDX41 increased in } \\
\text { cervical cancer. }\end{array}$ \\
\hline & DDX5 & $\begin{array}{c}\text { Mostly in nucleus, } \\
\text { cytoplasmic levels of DDX5 } \\
\text { increased in the G2/M phase }\end{array}$ & $\begin{array}{l}\text { p68 increased in a range of cancers except } \\
\text { for hepatocellular carcinoma }\end{array}$ \\
\hline & DDX3 & $\begin{array}{l}\text { Predominantly in nuclear } \\
\text { speckles and at low levels in } \\
\text { cytoplasm }\end{array}$ & See above \\
\hline
\end{tabular}




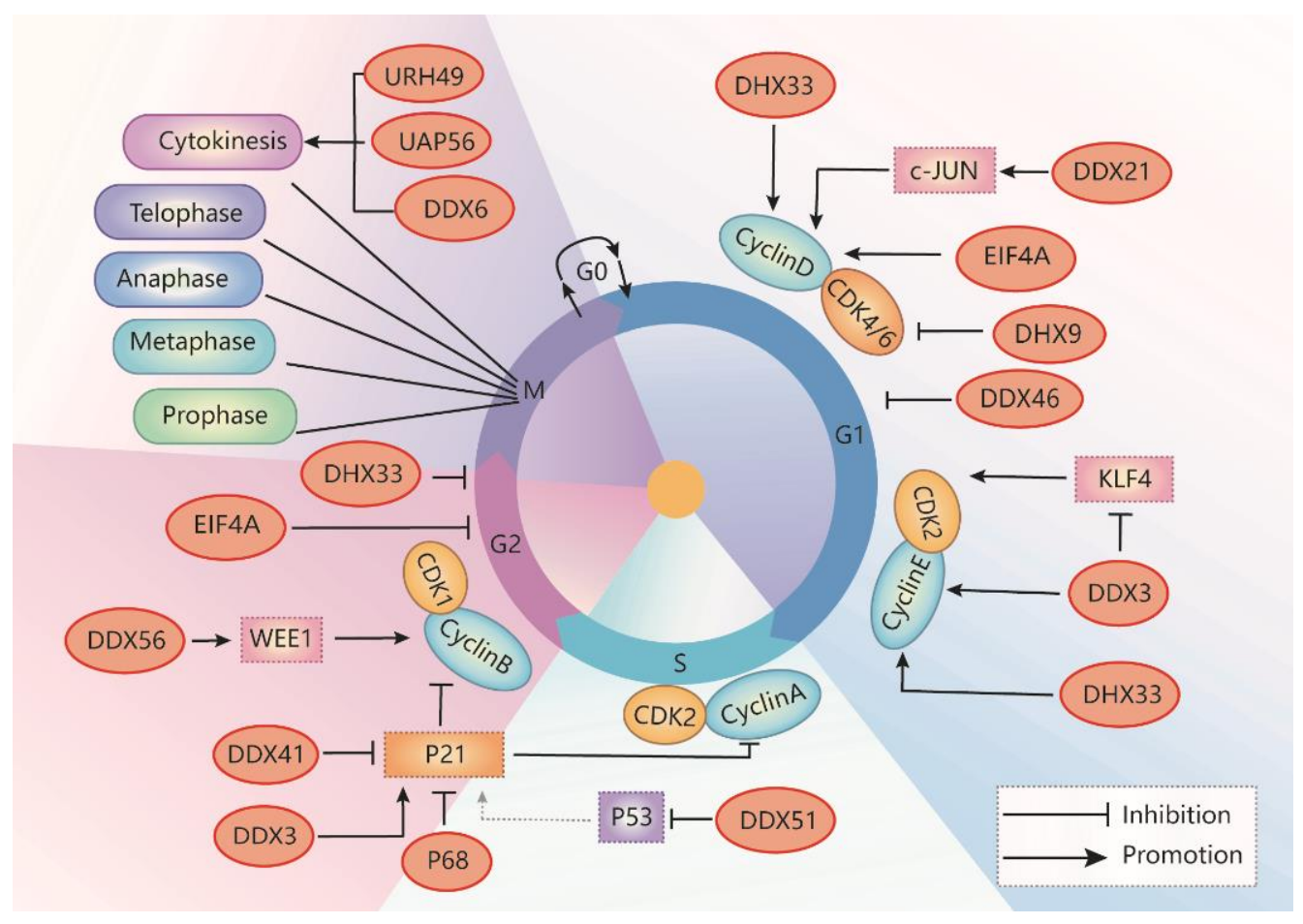

Figure 3. Schematic representation of the RNA helicases which are involved in the regulation of the cell cycle. RNA helicases are involved in G1/S transition: DDX3 positively regulates cyclin E1 translation but negatively regulates KLF4 expression to increase CDK2 expression. DHX33 initiates the transcription of E2F1, cyclin E2, cyclin D1, MMP9, MCMs, CDC6, and CDC20. DHX9 decreases the transcription of CDK6, leading to CIZ1 nuclear translocation. DDX21 activates c-Jun transcription, resulted in the increase of the synthesis of cyclin D1 mRNA. eIF4A regulates G1/S transition through regulation of the translation of cyclin D1, cyclin D2, and CDK6. RNA helicases are involved in S phase progression: DDX51 promotes $S$ phase progression, possibly through negative regulation of cell-cycle-related proteins, p53-p21. RNA helicases are involved in G2-M phase transition: DDX56 promotes $\mathrm{G} 2 / \mathrm{M}$ transition via the increase of intron retention and tumor suppressor WEE1 expression. RNA helicases are involved in mitotic phase progression: Knockdown of UAP56 or URH49 leads to mitosis defect. DDX6/CGH-1 functions to regulate microtubule cytoskeleton and chromosome separation. RNA helicases regulate the expression of CDK inhibitor p21: DDX41 and p68 inhibit p21 transcription and translation, respectively.

DHX33 plays a significant role in ribosome RNA synthesis and mRNA translation. DHX33 promotes numerous cellular processes, including cell cycle progression, apoptosis, and migration, by promoting the transcription of a subset of genes, including Bcl2, MMP9, MMP14, and urokinase-type plasminogen activator [51,52]. DHX33 is required for promoting cell cycle progression at the G1-to-S phase transition, which is overexpressed in several types of human cancers, such as lung cancers, hepatocellular carcinoma, lymphoma, colon cancer, and glioblastoma (Table 1) [16,51-54]. A deficiency of DHX33 induced a significant increase of G1-phase cells and a marked decrease of S-phase cells in different cancer cells [51,53-55]. Mechanically, DHX33 recruits active RNA polymerase II (Pol II) to the promoters of many cell-cycle-related genes, including cyclin E2, cyclin D1, E2F1, MMP9, MCMs, CDC6, and CDC20, and initiates the transcription of those genes [53,55] (Figure 3).

DHX9, as a multifunctional protein, regulates transcription, translation, miRNA processing, RNA transport, and genome maintenance processes [7,8,13,45]. DHX9 is overexpressed in several types of human cancers, including cervical cancer, breast cancer, prostate cancer, colorectal cancer, hepatocellular carcinoma, and Ewing sarcoma [56-59]. Knockdown of DHX9 arrests cell cycle at G0/G1phase (Table 1) [60]. DHX9 negatively regulates the expression of $\mathrm{CDK} 6$, an important protein for G1/S transition and cell division, 
through binding to the 3'-untranslated region (3'UTR) of CDK6 mRNA to decrease its stability and reducing polyribosome incorporation, resulting in the decrease of G1/S transition (Figure 3) [61]. In addition, DHX9 interacts with CIP1-interacting zinc finger protein 1 (CIZ1) to induce the translocation of CIZ1 to the nucleus during the S phase [62], which is necessary for the progression of the cell cycle [62]. DHX9 also regulates cell proliferation through interaction with EGF receptor, cAMP-response element-binding protein, BRCA1, and RNA polymerase II $[60,63]$.

DDX21, as an important nucleolar protein, plays a critical role in ribosomal RNA biogenesis and transcriptional regulation [64]. DDX21 is a transcriptional activator of c-Jun via their direct interaction to regulate mRNA expression of the downstream target genes, including EGFR and cyclin D1 [65]. DDX21 is dysregulated in colon cancer, lymphomas, neuroblastoma, and some breast cancers (Table 1) [17,66-68]. Upregulation of DDX21 promotes breast cancer cell proliferation by activation of the transcription factor AP-1 to regulate the transcription of cyclin D1 and rRNA processing, resulting in the increase of cells in the S phase (Figure 3) [65,69]. Deletion of DDX21 arrests cell cycle at G1/S transition in Hela cells [69]. In addition, DDX21 interacts with PARP-1 and results in its ADPRylation by PARP-1. Inhibition of PARP decreases the activity of DDX21 and suppresses cell proliferation in breast cancer cells [70].

The eIF4A family proteins regulate RNA biology, including transcription, translation, and degradation of mRNA [71,72]. eIF4A is also important for gene expression through translational regulation. The ribosome profiling analysis has identified eIF4A regulated genes that act at the G1/S phase transition, including Cyclin D1, Cyclin D2, and CDK6 (Figure 3) [73]. There are three paralogous genes of eIF4A, including eIF4A1, 2, and 3. eIF4A3 functions as an RNA-binding protein (RBP) and is a core component of the exon junction complex (EJC), which is mainly localized in the nucleus (Table 1) [74,75]. eIF4A3 is highly expressed in colorectal cancer [76]. The binding of eIF4A3 to LncRNA H19 prevents the recruitment of eIF4A3 to the mRNAs of the cell cycle regulators, including cyclin D1 and cyclin E1, for post-transcriptional modification, resulting in an acceleration of colon cancer cell growth [73,76].

DDX46, also named Prp5, has multiple functions in nuclear pre-mRNA splicing through the hydrolysis of ATP to rearrange local RNA-RNA or protein-RNA interactions [77]. The expression of DDX46 is upregulated in colorectal carcinoma, esophageal squamous cell carcinoma, gastric cancer, and osteosarcoma cells, and knockdown of DDX46 inhibits cancer cell proliferation, invasion and induces cell apoptosis (Table 1) [78-81]. Silence of DDX46 arrests cell cycle at G1 phase in esophageal squamous cell carcinoma cell lines (Figure 3) [79]. In addition, knockdown of DDX46 significantly reduced the phosphorylation of $A k t$ and $I \kappa B \alpha$. Whether DDX46 regulates G1/S phase transition through Akt and $I_{\kappa} \mathrm{B} \alpha$ needs to be further investigated.

\subsection{RNA Helicases Regulate S Phase Progression}

During the $S$ phase of the cell cycle, genetic materials, such as DNA, are synthesized for the duplication of the chromatin and reproduction of the whole genome, which is a pre-requisition for cell division. Once cells enter the $S$ phase, cyclin E/CDK2 complex needs to be silenced to eliminate the DNA re-replication [82]. Dissociation of CDK2 from cyclin E/CDK2 complex results in its association with the newly synthesized cyclin A to form CDK2/cyclin A complex, which can phosphorylate proteins that are necessary for completion of the $S$ phase. Alternatively, spliced p53 isoform (Delta-p53) transactivates the expression of endogenous p21, resulting in the inhibition of CDK2/cyclin A activity to and attenuate $S$ phase progression [83].

Thus far, only one RNA helicase, DDX51, has been associated with $S$ phase progression. It has been reported that downregulation of DDX51 leads to cell cycle arrest in the S phase (Figure 3) [84], probably through DDX51 mediated rRNA process and other signaling pathways. During the rRNA process, DDX51 interacts with pre-60S complexes and promotes the removal of U8 snoRNA from pre-rRNA, which is required for ribosome 
maturation [85]. DDX51 is also a negative regulator of p53, and thereby actively promotes cell proliferation [86]. In addition, DDX51 can promote breast cancer cell proliferation by increasing the activity of the Wnt/ $\beta$-catenin signaling pathway [26]. Moreover, DDX5 can promote cell proliferation by increasing the transcription of cyclin D1 in non-small cell lung carcinoma (Table 1) [87].

\subsection{RNA Helicases Regulate G2/M Phase Transition}

In the cell cycle, the G2 phase is the second gap for cells to prepare for mitosis (M phase). During the G2 phase, cyclin A is degraded, but cyclin B is synthesized, resulting in the association of Cdc2 with cyclin B, which is required for the initiation of mitosis. Cyclin B can be phosphorylated at Tyr15 by WEE1, a kinase of the WEE family, resulting in altering equilibria and affecting G2/M transition [88,89]. The initiation of G2 arrest, triggered by DNA damage or inappropriate replication, is important for DNA damage repair, which can be regulated through p53 mediated signaling pathways [90]. In addition, p21, as the downstream target of p53, is able to inhibit the activity of Cyclin A, Cyclin D, and other cell-cycle-related proteins, including cdc2 [40]. Different RNA helicases are associated with G2/M arrest.

DDX56 regulates diverse RNA metabolism, including transcription, translation, ribosome biogenesis, pre-mRNA splicing, and mRNA degradation. DDX56 is a component of free nucleoplasm $65 S$ preribosomal particles, which may participate in the assembly of the 605 ribosomal subunit. DDX56 has also been reported to regulate ribosome assembly through its association with the Oct4 and Sox 2 complex, which is necessary to maintain embryonic stem cells (ESCs) proliferation [91]. DDX56 is upregulated in osteosarcoma and colorectal cancer (Table 1) [92-94]. Depletion of the DDX56 arrest cell cycle in the G2/M phase via the decrease of tumor suppressor WEE1 expression, which functions as a G2/M DNA damage checkpoint (Figure 3) [94], results in the inhibition of cell proliferation and clone formation and the induction of p53 mediated apoptosis in osteosarcoma cells [92,93]. However, whether DDX56 regulates the cell cycle through p53-p21 signaling needs to be further investigated.

Furthermore, some RNA helicases that we mentioned above are also involved in $\mathrm{G} 2 / \mathrm{M}$ phase transition. It has been reported that knockdown of eIF4A3 decreases cell cycle arrest in the G2/M phase, but increases apoptosis [95]. DHX33 also positively regulates G2/M transition to promote cell cycle progression (Figure 3) [53].

\subsection{RNA Helicases Regulate Cytokinesis}

Cytokinesis is the last step of the cell cycle in which the cell must devotedly split the chromosomes and cytoplasm to produce two daughter cells with equal contents [96]. RNA helicases are involved in the key steps of cytokinesis, including the assembly and contraction of the contractile network, the formation of the mitotic spindle, and the interaction between the microtubule and cortical actomyosin cytoskeleton [97].

UAP56 and its paralog URH49 are 90\% identical to each other. These RNA helicases are nuclear RNA helicases essential for mRNA export and splicing and piRNA biogenesis. They also localize at cytoplasm (Table 1). Knockdown of UAP56 often results in premature sister chromatid separation, whereas knockdown of URH49 leads to chromosome arm resolution defects and failure of cytokinesis (Figure 3) [98,99]. Knockdown of UAP56 affects the expression of distinct mRNAs necessary for normal mitosis, such as BRCA1, and knockdown of URH49 resulted in the downregulation of survivin/BIRC5 and PRC1 mRNAs to regulates cytokinesis [98]. Recently, it has been reported that URH49 also regulates cytokinesis by the regulation of the expression of two CPC complex components, AURKB and BIRC5, which are associated with the cell cycle [99].

DDX6, also named CGH-1 in Caenorhabditis elegans [100], is highly conserved from unicellular eukaryotes to vertebrates [100]. DDX6 functions as an oncogene in colorectal cancer and hepatocellular carcinoma (Table 1). Knockdown of DDX6 inhibits tumor cell growth through down-regulation of c-Myc [101]. CGH-1 and its orthologs are found in 
dynamic ribonucleoprotein complexes, which contributes to global and transcript-specific mRNA storage, translational repression during development and cell differentiation. CGH1 is also localized to RNA-containing P-granules, which are RNA/protein condensates in the germline of $C$. elegans [102]. CGH-1 regulates the recruitment of Aurora B kinase and ZEN-4, between the separating chromosomes. Partial depletion of CGH-1 in worms results in assembly defects of interzonal microtubule bundles and the failure of cytokinesis that becomes remarkable after anaphase onset (Figure 3) [102].

\subsection{RNA Helicases Target CDK Inhibitor $p 21$}

CDK inhibitors (CKIs) are mainly identified in CIP/KIP and INK4 families, which are key regulators of G1, S, and G2 phase transitions during the cell cycle [103]. The CKI inhibitors in the CIP/KIP family, including p21, p27, and p57, target CDK1, CDK2, CDK4, and CDK6. The CKI inhibitors in the INK4 family, including p15, p16, p18, and p19, also targets CDK4 and CDK6. The expression and stability of CKIs are regulated by multiple mechanisms, including transcriptional, post-transcriptional, epigenetic regulation, and ubiquitin-dependent or independent protein degradation. P21 is one of the most studied CDK1 inhibitors, which was first identified as a CDK-interacting protein (CIP1) and wild-type p53-activated factor 1 (WAF1). P21 can bind to cyclin A/CDK2 [104], cyclin E/CDK2 [105], cyclin D/CDK4 [106], and cyclin B/CDK1 complexes [107], resulting in cell cycle arrest in the S phase, G1/S transition, and G2/M transition. We will discuss how p21 is regulated by different RNA helicases.

DDX41 is involved in all aspects of RNA biology [108]. Mutation of DDX41 alters pre-mRNA splicing and RNA processing, resulting in the loss of its tumor suppressor function [109]. DDX41 can function as a repressor of p21, which can bind to the $3^{\prime} U T R$ of the p21 mRNA to inhibit its translation of under basal and stress conditions (Figure 3). Mutation of DDX41 (G521S) results in the loss of its ATP hydrolysis activity and its ability to regulate p21 translation [103]. Mutation of DDX41 also induces alternative splicing and misexpression of cell cycle genes, such as cyclin E2, CKI 1A in erythroid progenitor cells, resulting in diminished proliferation and defective differentiation, finally leading to anemia and acute myeloid leukemia (Table 1) [109,110]. In addition, the DDX41 mutant can activate DNA damage response, leading to an Ataxia-telangiectasia mutated [17] and Rad3-related (ATR)-triggered cell cycle arrest [103]. These findings make DDX41 an important player in the regulation of the cell cycle and DNA damage response.

RNA helicase DDX5/p68 is involved in multiple cellular processes, including transcription, pre-mRNA and rRNA processing, and miRNA processing. Overexpression of p68 promotes the development of breast cancer, colorectal tumors, prostate cancer, and leukemia, suggesting that 668 plays an important role in cancer development and progression (Table 1) [34]. DDX5/p68 can function as a transcriptional co-activator and can be recruited to the promoters of its target genes together with the activated transcription factors. In particular, p68 is selectively required for p53-dependent p21 expression by promoting the recruitment of p53 and RNA polymerase II to the $\mathrm{p} 21$ promoter, leading to cell-cycle arrest after DNA damage [111]. Knockdown of p68 enhanced the transcription of p21 but decreased the expression of the beta-catenin-regulated genes, including c-Myc, cyclin D1, and c-Jun [112]. Deletion of p68 results in a loss of the G1/S checkpoint, allowing cell cycle progression through the $S$ to $\mathrm{G} 2 / \mathrm{M}$ phases (Figure 3). We recently showed that p68, also via its interaction with p53, negatively regulates the expression of the Pkd1 gene to promote cystic cell proliferation and inhibit apoptosis in ADPKD $[19,113]$. Whether p68 is involved in the regulation of other cell-cycle-related factors in ADPKD needs to be further investigated. In addition, DDX5 also interacts with Tat, an RNA binding protein, and may enhance the availability of P-TEFb through expropriating HEXIM1, and acting as a necessary cellular factor for efficient HIV transcription elongation [114].

DDX3 has also been identified as a positive regulator of p21 [41,42]. Overexpression of DDX3 decreases the S-phase population via upregulation of p21 transcription (Figure 3), resulting in the inhibition of lung cancer cell growth [42]. In contrast, downregulation 
or loss of nuclear localization of DDX3 promoted tumor growth in hepatocellular carcinoma [41]. DDX3 transactivates p21 promoter through the regulatory elements located upstream of the transcription start site, including six Sp1 sites, two E2F sites, and one AP-2 site [41]. DDX3 mediated transcriptional modulation on the $\mathrm{p} 21$ promoter depends on its ATPase activity but not helicase activity [41]. Thus, DDX3 inhibitors can affect the cell cycle through the regulation of the translation of cell cycle regulators, including cyclin E1 and KLF4, and key CDK inhibitor, p21.

\section{Development of RNA Helicase Inhibitors for Clinical Treatment}

\subsection{Different Targeting Strategies Are Used to Develop Compounds against RNA Helicases}

The important roles of RNA helicases in the regulation of the cell cycle, cell proliferation, cellular transformation, apoptosis, and cell adhesion and motility make RNA helicases an active targets of drug development for the treatment of viral infections, neurodegenerative diseases, and cancers. Based on the crystal structures and the mechanism(s) of activity of the enzymes, specific and selective inhibitors for RNA helicases have been designed. In general, inhibitors targeting RNA helicase activity could act via one or more of the mechanisms: (1) inhibition of the ATPase activity of RNA helicases by interference with ATP binding and result in limiting the energy necessary for the unwinding and translocation; (2) inhibition of the helicase activity by competitively occupying the RNA binding site of the RNA helicases; and (3) stabilization of RNA helicases onto RNA, resulting in the inhibition of translation initiation.

\subsubsection{Compounds That Inhibit the ATPase Activity of RNA Helicase}

RX-5902 is a first-in-class anticancer compound targeting phosphorylated p68 (Table 2). RX-5902 interacts with the Y593 of the phosphorylated p68, resulting in a large diminishment of nuclear $\beta$-catenin, and this regulation is dependent on the ATPase activity of p68 [115].

Compound 18 is an eIF4A inhibitor, which has been identified from a high throughput screening (HTS) campaign. Compound 18 selectively acts against eIF4A through competitive inhibition of its ATPase activity (Table 2) [116].

\subsubsection{Compounds That Inhibit the Helicase Activity of RNA Helicases}

RK-33 (diimidazo[4,5-d:4' $\left.4^{\prime} 5^{\prime}-\mathrm{f}\right]-[1,3]$ diazepine), a small molecule, is a ring-expanded nucleoside (REN) analogue. RK-33 is designed to selectively inhibit DDX3 activity but no other DEAD-box RNA helicases by binding to the ATP pocket of DDX3 (Table 2) [117]. Treatment with RK-33 reduces tumor growth or tumor cell proliferation in xenograft mouse models of Ewing sarcoma, lung cancer, and prostate cancer by inducing G1 cell cycle arrest and apoptosis $[33,47,118]$. NZ51 is another DDX3 inhibitor, which has been shown to competitively occupy the RNA binding site of DDX3 to suppress its RNA helicase activity without affecting its ATPase activity (Table 2).

Hippuristanol, as a polyoxygenated steroid, selectively inhibits eIF4A through binding to its C-terminal domain [119]. Hippuristanol suppresses the RNA-binding activity of eIF4A by locking eIF4A in a closed conformation, but does not prevent its ATP-binding activity (Table 2) [72,120].

3.1.3. Compounds That Stabilize RNA Helicases onto RNA, Resulting in the Inhibition of Translation Initiation

Both Silvestrol and CR-1-31-B have been identified as specific inhibitors of the eIF4A, which act as the part of the translation initiation complex that binds to the $5^{\prime}$-cap structure (Table 2) [32,73]. The potential mechanism for these compounds to inhibit eIF4A is through increasing the affinity of eIF4A to its target mRNA to stall eIF4A on its RNA substrate, which results in a consumption of eIF4A from eIF4F-mRNA complexes [32,73]. 
Table 2. The Structures and Sites of Action of RNA Helicase Inhibitors in Diseases.

\begin{tabular}{|c|c|c|c|c|c|c|}
\hline $\begin{array}{c}\text { RNA } \\
\text { Helicases }\end{array}$ & Inhibitors & Chemical Structure & $\begin{array}{c}\text { Mechanisms } \\
\text { of Action }\end{array}$ & Diseases & Model & $\begin{array}{c}\text { Toxicity or } \\
\text { Tissue-Specific }\end{array}$ \\
\hline \multirow{3}{*}{ DDX3 } & RK-33 & & $\begin{array}{c}\text { Inhibition of } \\
\text { helicase } \\
\text { activity }\end{array}$ & $\begin{array}{l}\text { Lung cancer, } \\
\text { medulloblas- } \\
\text { toma, prostate } \\
\text { cancer, Ewing } \\
\text { sarcoma, and } \\
\text { colorectal } \\
\text { cancer }\end{array}$ & $\begin{array}{l}\text { In vitro, } \\
\text { and } \\
\text { animal } \\
\text { models }\end{array}$ & $\begin{array}{l}\text { No discernable } \\
\text { toxicity in } \\
\text { animal models }\end{array}$ \\
\hline & NZ51 & & $\begin{array}{c}\text { Inhibition of } \\
\text { helicase } \\
\text { activity }\end{array}$ & Breast cancer & In vitro & Not clear \\
\hline & Doxorubicin & & $\begin{array}{c}\text { Inhibition of } \\
\text { ATPase } \\
\text { activity }\end{array}$ & $\begin{array}{l}\text { Oral squamous } \\
\text { cell carcinoma }\end{array}$ & In vitro & Cardiotoxicity \\
\hline \multirow{5}{*}{ eIF4A } & Compound 18 & & $\begin{array}{c}\text { Inhibition of } \\
\text { ATPase } \\
\text { activity }\end{array}$ & $\begin{array}{l}\text { Exon junction } \\
\text { complex }\end{array}$ & NA & $\begin{array}{c}\mathrm{IC}_{50}: 0.97 \\
\mu \mathrm{mol} / \mathrm{L}\end{array}$ \\
\hline & Silvestrol & & $\begin{array}{c}\text { Stabilization } \\
\text { of RNA } \\
\text { helicase } \\
\text { onto RNA }\end{array}$ & Breast cancer & In vitro & $\begin{array}{c}\text { Not toxic } \\
\text { in vitro and } \\
\text { in vivo at } \\
\text { concentrations } \\
\text { of effective } \\
\text { activity }\end{array}$ \\
\hline & Hippuristanol & & $\begin{array}{c}\text { Inhibition of } \\
\text { helicase } \\
\text { activity }\end{array}$ & Leukemia & In vitro & Not clear \\
\hline & CR-1-31-B & & $\begin{array}{c}\text { Stabilization } \\
\text { of RNA } \\
\text { helicase } \\
\text { onto RNA }\end{array}$ & Breast cancer & In vitro & Not clear \\
\hline & Pateamine A & & $\begin{array}{l}\text { Regulation } \\
\text { of ATPase } \\
\text { and RNA } \\
\text { helicase } \\
\text { activity }\end{array}$ & Melanoma & $\begin{array}{l}\text { In vitro, } \\
\text { and } \\
\text { animal } \\
\text { models }\end{array}$ & $\begin{array}{l}\text { Low toxicity to } \\
\text { quiescent cells }\end{array}$ \\
\hline DDX6 & $R X-5902$ & & $\begin{array}{c}\text { Inhibition of } \\
\text { ATPase } \\
\text { activity }\end{array}$ & TNBC & $\begin{array}{c}\text { In vitro, } \\
\text { preclinical } \\
\text { models of } \\
\text { TNBC, } \\
\text { phase I } \\
\text { study }\end{array}$ & Not clear \\
\hline
\end{tabular}




\subsubsection{Compounds That Regulate Both ATPase and RNA Helicase Activities}

Pateamine A (Pat A) is designed as a biologically active metabolite, which selectively stimulates the RNA binding activity of eIF4A, resulting in disruption of the eIF4F complex and leading to inhibition of cap-dependent translation. Pat A also increases the ATPase and helicase activities of eIF4A [121]. Pat A can disrupt the interaction of eIF4A-eIF4G and free eIF4A from the eIF4F complex. In addition, Pat A also promotes the formation of the eIF4A homodimer and the interaction of eIF4A-eIF4B (Table 2) [121,122].

\subsection{The Therapeutic Potential of RNA Helicase Inhibitors in the Treatment of Various Disorders}

As described above, different inhibitors of RNA helicases have been developed, which may potentially be used in disease treatment $[47,123,124]$. Here, we mainly focus on inhibitors that target DDX3, eIF4A, and DDX5 (p68) in the treatment of diseases.

The DDX3 inhibitor, NZ51, is able to block the ATP-dependent helicase activity of DDX3. NZ51 suppresses DDX3 activity at low micromole concentration and displays anti-proliferative activity by inhibiting cell replication at the G1 phase in aggressive breast cancer cells [43,49]. However, treatment with NZ51 did not significantly reduce tumor growth in breast cancer mouse model [49]. Doxorubicin, an antitumor drug, can inhibit the ATPase activity of DDX3, which shows anticancer activity on human oral squamous cell carcinoma cells. However, the cardiotoxicity is a limitation for doxorubicin in vivo [125]. The DDX3 inhibitors, RK-33, can bind with the ATP-binding domain of DDX3 to block its helicase activity. RK-33 can also disrupt the DDX3- $\beta$-catenin complex, resulting in an interference of Wnt signaling and regulating cell differentiation, cell proliferation, and G1/S transition [33]. The highest RK-33 sensitivity was observed in tumor cells. Treatment with RK-33 inhibited the growth of colorectal cancer cell lines and promoted cell death with IC50 values ranging from 2.5 to $8 \mu \mathrm{M}$ [48]. RK-33 also inhibits the growth of other cancer cells in vitro, including lung cancer, medulloblastoma, and prostate cancer [44,46-48]. Importantly, RK-33 can reduce not only the toxicities associated with the treatment but also the dose of radiation to $5 \mathrm{~Gy}$ in the medulloblastoma treatment of a mouse xenograft model [44], suggesting that RK-33 can increase radio-sensitization. The safety and efficacy of this combined treatment in human diseases should be evaluated in future clinical trials. Treatment with RK-33 also changes the Ewing sarcoma cellular proteome, including the proteins involved in DNA replication, mRNA translation, and proteasome function [126]. Treatment with RK-33 inhibits the growth of human Ewing sarcoma xenografts, without overt toxicity [126]. In addition, RK-33 attenuates the assembly of stress granules (SGs), one type of mRNA-containing cytoplasmic aggregates, formed in response to global translation arrest or to various stress conditions, such as reactive oxygen species, heat, starvation, and viral infection. Thus, RK33 may be relevant for the treatment of stress granules-dependent pathologies, including viral infection, tumor resilience, and neurodegeneration [117]. The Advancement of RK-33 to clinical trials may represent a novel therapeutic strategy, especially for cancer treatment in the future (Table 2).

Hippuristanol, as a pan eIF4A inhibitor, has been reported to inhibit human T lymphotrophic virus type 1-infected T-cell line and adult T-cell leukemia cell proliferation by promoting cell cycle arrest at the G1 phase and suppressing the expression of cell cycle proteins and cyclin-dependent kinases, and inducing apoptosis by decreasing the expression levels of Bcl-x, baculoviral IAP repeat, containing 3 X-linked inhibitors of apoptosis (xIAP) and caspase 8 and FADD like apoptosis regulator $[127,128]$. Treatment with hippuristanol significantly inhibited the growth and invasion of primary effusion lymphoma cells compared with untreated mice [129]. Silvestrol, a selective eIF4A inhibitor, has been reported to inhibit eIF4A in MDA-MB-231 cells, resulting in the blocking of cell cycle progression at the G1/S phase transition, possibly through a decrease in the expression of cyclin D1, cyclin $\mathrm{D} 2$, and CDK6, and the induction of apoptosis through inhibition of the translation of Bcl2 [73]. CR-1-31-B, another eIF4A inhibitor, suppresses a panel of relevant key cell-cycle regulators, including cyclin D1, CDK2, and CDK4, in MCF-7 and T47D cells at a low dose, and suppresses cyclin E1, cyclin A2, and CDK6 in those cells at higher doses. CR-1-31-B 
can enhance G1 phase arrest induced by CDK4/6 inhibition [32]. Moreover, treatment with allosteric eutomer inhibitors (T-595) of eIF4A3 results in cell cycle arrest at the G2/M boundary and increases apoptosis [95]. Pateamine A also inhibits the activity of eIF4A. Des-methyl, des-amino pateamine A (DMDA-PatA) is a structurally simplified analogue of the marine natural product pateamine A [130]. Treatment with DMDA-PatA rapidly stops DNA synthesis in the $S$ phase, which shows potent anticancer activity in MDA-MB-435 cells and LOX melanoma cell lines $[130,131]$. These studies suggest that targeting eIF4A might be a promising therapeutic strategy for cancer treatment (Table 2).

DDX5 (p68) can be phosphorylated at the Y593 site by growth factors, including platelet-derived growth factor, to increase cellular proliferation, epithelial to mesenchymal transition (EMT), malignant transformation, cell migration, and oncogenesis through translocation of $\beta$-catenin to nuclear and activation of cyclin D1, c-JUN, and c-MYC [132]. RX-5902 is a small molecule inhibitor of phosphorylated p68 (p-p68), which can decrease the nuclear localization of $\beta$-catenin in murine triple-negative breast cancer models [124]. Treatment with RX-5902 decreases the expression of genes that are regulated by the $\beta$ catenin pathway, such as c-Myc, cyclin-D1, and c-Jun, in cancer cells, resulting in the inhibition of cancer cell proliferation $[115,133]$. RX-5902 has been assessed in a first-inhuman phase I dose-escalation study (clinical trial identification: NCT02003092) (Table 2). This study suggests that RX-5902 is well tolerated with a favorable side effect profile [134]. The recommended phase 2 dose for RX-5902 is $250 \mathrm{mg}$, which can be administered daily for 5 on/ 2 days off with continuous dosing in patients with metastatic triple-negative breast cancer [134]. The preclinical research and clinical trial indicate that RX-5902 might be a promising therapeutic strategy for breast cancer; the role of RX-5902 on other diseases needs to be further investigated.

\section{RNA Helicases and Phase-Separated Organelles}

Recently, several studies have demonstrated that the DEAD-box RNA helicases involved in regulation of liquid-liquid phase separation (LLPS) play a crucial role in the formation of RNA-containing membrane-less organelles, including pericentriolar material (PCM), stress granules (SGs), P bodies, and P granules in Caenorhabditis elegans [135].

Pericentriolar material is defined as a matrix of proteins surrounding the two barrelshaped centrioles during mitosis, which serves as a platform for protein complexes to regulate organelle trafficking, protein degradation, and spindle assembly. PCM are highly dynamic, spherical organelles without a membrane. Zwicker et al. [136] used the concept of phase separation and proposed a theoretical description of centrosomes as liquid droplets. Gle1 is a highly conserved molecule of RNA-dependent DEAD-box ATPase proteins, which is enriched at the centrosome and basal body. Gle1 can be assembled into the toroid-shaped pericentriolar material around the mother centriole. Reduction of Gle1 is correlated with decreased pericentrin localization at the centrosome and microtubule organization defects that may be involved in the regulation of cell cycle progression through spindle assembly checkpoint [137].

Stress granules are RNPs that assemble in response to environmental stresses such as oxidative stress, heat shock, or osmotic shock. One component of yeast stress granules is Ded1p, also named DDX3 in mammalian. Temperature-driven liquid phase condensation of Ded1p induces the sequestration of housekeeping mRNAs and promotes an expanded heat shock response in program results of the preferential expression of stress proteins at $39{ }^{\circ} \mathrm{C}$ [138]. Targeting the ATPase activity of DDX3 by RK-33 reduces the assembly of SG, only marginally affect the disassembly of SGs [117]. In contrast, Begovich et al. [139] found that decrease of the ATPase activity of Ded1 promotes SG formation in an in vitro assembled SGs (IVSGs) system. They also showed that ATP not only suppresses IVSG formation but also act as an energy source for disassembly and remodeling of IVSGs. These findings suggested that ATP may act as a biological hydro trope to prevent proteins from phase separating, indicating a nonenzymatic role for ATP in SG assembly. Given the 
findings of ATP-dependent RNA helicases on the regulation of SG dynamics, this field might get more attention in the future.

$\mathrm{P}$ bodies are the large cytoplasmic granules, which are membrane-less cytoplasmic organelles that form via phase-separation once RNAs and nearby RBPs assemble into ribonuclear particle (RNP) granules. P bodies have all the key characters of LLPS, which are liquid-like, spherical, and dynamic, and can be dissolved by the alcohol 1,6-hexanediol. One of the key regulators that regulates P bodies' assembly is the DEAD-box ATPase Dhh1 (DDX6 in humans). Dhh1, as an enhancer of decapping, is involved in the translational repression of mRNAs. Dhh1 is involved in phase separation and controls $\mathrm{P}$ bodies dynamics in vivo, which is mainly dependent on its RNA-stimulated ATPase activity. The ATPase activator Not1 dissolves Dhh1 droplets in vitro and inhibits P-body formation in vivo [140]. P bodies' formation can also be promoted by Pat1 through enhancing the Dhh1-regulated LLPS [141]. Pat1 is a conserved multi-domain RNA binding protein, which may directly counteract the Not1-stimulated ATPase activation of Dhh1 to regulate P bodies formation. A recent study indicated that the helicase activity of DDX6 is not only essential for P-body assembly but is also required for exit from the pluripotent state and for hPSC differentiation [142]. Furthermore, depletion of DDX6 on mesodermal progenitor revealed that thousands of genes were aberrantly expressed as examined by RNA-sequence (1366 genes upregulated; 1040 genes downregulated). Moreover, the upregulated genes were associated with cell differentiation, downregulated genes were related to cell cycle progression. However, the direct connection between cell cycle progression and P bodies needs to be further investigated.

$\mathrm{P}$ granules are RNA/protein condensates in the germline of Caenorhabditis elegans. $\mathrm{P}$ granules are membrane-less organelles that may assemble by intracellular phase separation. GLH-1, a germline putative RNA helicase, regulates the formation and disassembly of $P$ granules coupling with distinct steps of its ATPase hydrolysis cycle [143]. PGL-1 and PGL-3 are the self-assembling P-granule proteins, contain RG-repeats sequences. PGL-1 is also required to localize FBF-2 to perinuclear $P$ granules and for efficient binding of FBF-2 to its mRNA targets, resulted in preventing translation of meiotic mRNAs [144]. In addition, DEAD-box helicases LAF-1 and VBH-1 also contain RG-repeats sequences, indicating that LAF-1 and VBH-1 may transiently associate with P granules [145].

DDXs globally promote phase separation in their ATP- and RNA-bound state. ATP hydrolysis induces the release of RNA clients from a DDX, results in the disassembly of RNA-containing membrane-less organelles [135]. The condensates formed by 2NT$\mathrm{DDX} 4{ }^{\mathrm{YFP}}$, a recombinant protein, dissolve during mitosis and leads to increasing of noise in protein concentration. In contrast, droplets reform in most postmitotic cells and decrease the noise in protein concentration. These findings indicate that the RNA helicases play an important role in phase separation [146]. The potential of RNA helicases mediated phase separation in cell cycle control is a perspective direction for further investigation.

\section{Conclusions}

RNA helicases are highly conserved enzymes important for RNA metabolism, which are involved in multiple steps of cell cycle regulation (Figure 3). RNA helicases are involved in cell cycle regulation at each phase with different mechanisms of action, including the regulation of (1) pre-mRNA transcription or splicing of some cell cycle regulators, (2) translation of cell cycle stage associated cyclins and CDKs, and (3) transcriptional and post-translational modification of the effectors, such as $\mathrm{p} 21$, that are involved in cell cycle progression. For example, DDX3 regulates the expression of cyclin A1, cyclin E1, and CDK2. DHX33 regulates the transcription of many cyclins and CDKs. DDX21 regulates the expression of cyclin D1. DDX56 regulates the expression of WEE1, a G2-M cell cycle checkpoint gene. DDX5 (p68) is involved in the expression of cyclin D1, which is also important for p53 activation. DHX9 regulates the formation of cyclin D-CDK complex. DDX46 regulates G1/S cell cycle arrest. DDX41 is a repressor of CDK inhibitors, such as p21. The effect of RNA helicases on cell cycle progression is cell-type dependent, and 
targeting RNA helicases with inhibitors should have a significant effect on the control of cell cycle and cell proliferation. Small molecule inhibitors of RNA helicases have already been developed based on the crystal structures and the mechanism(s) of action of these enzymes. These inhibitors have been validated in vitro and in vivo, which may be further tested in different diseases, including cancer and ADPKD, as a potential therapeutic strategy.

Author Contributions: Conceptualization, L.Z. and X.L.; manuscript draft preparation L.Z.; revision and editing L.Z. and X.L. All authors have read and agreed to the published version of the manuscript.

Funding: This work was supported by the National Institutes of Health grant R01 DK084097, R01 DK126662, and the PKD Foundation research grant (X.Li), and the National Natural Science Foundation of China (grant 81800614) (L. Zhang).

Institutional Review Board Statement: Not applicable.

Informed Consent Statement: Not applicable.

Data Availability Statement: Not applicable.

Conflicts of Interest: The authors declare no conflict of interest.

\section{References}

1. Panagopoulos, A.; Altmeyer, M. The Hammer and the Dance of Cell Cycle Control. Trends Biochem. Sci. 2021, 46, 301-314. [CrossRef]

2. Guiducci, G.; Stojic, L. Long Noncoding RNAs at the Crossroads of Cell Cycle and Genome Integrity. Trends Genet. 2021, 37, 528-546. [CrossRef]

3. Jongsma, M.L.; Berlin, I.; Neefjes, J. On the move: Organelle dynamics during mitosis. Trends Cell Biol. 2015, 25, 112-124. [CrossRef]

4. Lemmens, B.; Lindqvist, A. DNA replication and mitotic entry: A brake model for cell cycle progression. J. Cell Biol. 2019, 218, 3892-3902. [CrossRef] [PubMed]

5. Martinez-Alonso, D.; Malumbres, M. Mammalian cell cycle cyclins. Semin. Cell Dev. Biol. 2020, 107, 28-35. [CrossRef] [PubMed]

6. Zieske, J.D.; Francesconi, C.M.; Guo, X. Cell cycle regulators at the ocular surface. Exp. Eye Res. 2004, 78, 447-456. [CrossRef]

7. Cordin, O.; Banroques, J.; Tanner, N.K.; Linder, P. The DEAD-box protein family of RNA helicases. Gene 2006, 367, 17-37. [CrossRef]

8. Fuller-Pace, F.V. DExD/H box RNA helicases: Multifunctional proteins with important roles in transcriptional regulation. Nucleic Acids Res. 2006, 34, 4206-4215. [CrossRef] [PubMed]

9. Jarmoskaite, I.; Russell, R. DEAD-box proteins as RNA helicases and chaperones. Wiley Interdiscip. Rev. RNA 2011, 2, 135-152. [CrossRef]

10. Cordin, O.; Hahn, D.; Beggs, J.D. Structure, function and regulation of spliceosomal RNA helicases. Curr. Opin. Cell Biol. 2012, 24, 431-438. [CrossRef] [PubMed]

11. Owttrim, G.W. RNA helicases: Diverse roles in prokaryotic response to abiotic stress. RNA Biol. 2013, 10, 96-110. [CrossRef]

12. Soultanas, P.; Wigley, D.B. Unwinding the 'Gordian knot' of helicase action. Trends Biochem. Sci. 2001, 26, 47-54. [CrossRef]

13. Bourgeois, C.F.; Mortreux, F.; Auboeuf, D. The multiple functions of RNA helicases as drivers and regulators of gene expression. Nat. Rev. Mol. Cell Biol. 2016, 17, 426-438. [CrossRef] [PubMed]

14. Ali, M.A.M. DEAD-box RNA helicases: The driving forces behind RNA metabolism at the crossroad of viral replication and antiviral innate immunity. Virus Res. 2021, 296, 198352. [CrossRef]

15. Wang, Y.; Li, G.; Deng, M.; Liu, X.; Huang, W.; Zhang, Y.; Liu, M.; Chen, Y. The multifaceted functions of RNA helicases in the adaptive cellular response to hypoxia: From mechanisms to therapeutics. Pharmacol. Ther. 2020, 221, 107783. [CrossRef]

16. van Voss, M.R.H.; van Diest, P.J.; Raman, V. Targeting RNA helicases in cancer: The translation trap. Biochim. Biophys. Acta. Rev. Cancer 2017, 1868, 510-520. [CrossRef]

17. Putra, V.; Hulme, A.J.; Tee, A.E.; Sun, J.Q.; Atmadibrata, B.; Ho, N.; Chen, J.; Gao, J.; Norris, M.D.; Haber, M.; et al. The RNA-helicase DDX21 upregulates CEP55 expression and promotes neuroblastoma. Mol. Oncol. 2021, 15, 1162-1179. [CrossRef]

18. Wolfe, A.L.; Singh, K.; Zhong, Y.; Drewe, P.; Rajasekhar, V.K.; Sanghvi, V.R.; Mavrakis, K.J.; Jiang, M.; Roderick, J.E.; Van der Meulen, J.; et al. RNA G-quadruplexes cause eIF4A-dependent oncogene translation in cancer. Nature 2014, 513, 65-70. [CrossRef] [PubMed]

19. Zhang, L.; Li, L.X.; Zhou, J.X.; Harris, P.C.; Calvet, J.P.; Li, X. RNA helicase p68 inhibits the transcription and post-transcription of Pkd1 in ADPKD. Theranostics 2020, 10, 8281-8297. [CrossRef] [PubMed]

20. Mo, J.; Liang, H.; Su, C.; Li, P.; Chen, J.; Zhang, B. DDX3X: Structure, physiologic functions and cancer. Mol. Cancer 2021, 20, 38. [CrossRef] [PubMed]

21. Wisskirchen, C.; Ludersdorfer, T.H.; Müller, D.A.; Moritz, E.; Pavlovic, J. The cellular RNA helicase UAP56 is required for prevention of double-stranded RNA formation during influenza A virus infection. J. Virol. 2011, 85, 8646-8655. [CrossRef] 
22. Ghosh, S.; Thakur, M.K. Interaction of estrogen receptor-alpha transactivation domain with nuclear proteins of mouse brain: p68 RNA helicase shows age- and sex-specific change. J. Neurosci. Res. 2009, 87, 1323-1328. [CrossRef] [PubMed]

23. Lennox, A.L.; Hoye, M.L.; Jiang, R.; Johnson-Kerner, B.L.; Suit, L.A.; Venkataramanan, S.; Sheehan, C.J.; Alsina, F.C.; Fregeau, B.; Aldinger, K.A.; et al. Pathogenic DDX3X Mutations Impair RNA Metabolism and Neurogenesis during Fetal Cortical Development. Neuron 2020, 106, 404-420.e8. [CrossRef] [PubMed]

24. Nicklas, S.; Okawa, S.; Hillje, A.L.; González-Cano, L.; Del Sol, A.; Schwamborn, J.C. The RNA helicase DDX6 regulates cell-fate specification in neural stem cells via miRNAs. Nucleic Acids Res. 2015, 43, 2638-2654. [CrossRef]

25. Nyamao, R.M.; Wu, J.; Yu, L.; Xiao, X.; Zhang, F.M. Roles of DDX5 in the tumorigenesis, proliferation, differentiation, metastasis and pathway regulation of human malignancies. Biochim. Biophys. Acta Rev. Cancer 2019, 1871, 85-98. [CrossRef] [PubMed]

26. Wang, Z.; Luo, Z.; Zhou, L.; Li, X.; Jiang, T.; Fu, E. DDX5 promotes proliferation and tumorigenesis of non-small-cell lung cancer cells by activating beta-catenin signaling pathway. Cancer Sci. 2015, 106, 1303-1312. [CrossRef]

27. Wang, R.; Jiao, Z.; Li, R.; Yue, H.; Chen, L. p68 RNA helicase promotes glioma cell proliferation in vitro and in vivo via direct regulation of NF-kappaB transcription factor p50. Neuro. Oncol. 2012, 14, 1116-1124. [CrossRef]

28. Guturi, K.K.; Sarkar, M.; Bhowmik, A.; Das, N.; Ghosh, M.K. DEAD-box protein p68 is regulated by beta-catenin/transcription factor 4 to maintain a positive feedback loop in control of breast cancer progression. Breast Cancer Res. 2014, 16, 496. [CrossRef]

29. Sha, M.; Lin, M.; Wang, J.; Ye, J.; Xu, J.; Xu, N. Long non-coding RNA MIAT promotes gastric cancer growth and metastasis through regulation of miR-141/DDX5 pathway. J. Exp. Clin. Cancer Res. 2018, 37, 58. [CrossRef]

30. Bertoli, C.; Skotheim, J.M.; de Bruin, R.A. Control of cell cycle transcription during G1 and S phases. Nat. Rev. Mol. Cell Biol. 2013, 14, 518-528. [CrossRef]

31. Cannizzaro, E.; Bannister, A.J.; Han, N.; Alendar, A.; Kouzarides, T. DDX3X RNA helicase affects breast cancer cell cycle progression by regulating expression of KLF4. FEBS Lett. 2018, 592, 2308-2322. [CrossRef]

32. Kong, T.; Xue, Y.; Cencic, R.; Zhu, X.; Monast, A.; Fu, Z. eIF4A Inhibitors Suppress Cell-Cycle Feedback Response and Acquired Resistance to CDK4 / 6 Inhibition in Cancer. Mol. Cancer Ther. 2019, 18, 2158-2170. [CrossRef]

33. Chen, H.H.; Yu, H.I.; Cho, W.C.; Tarn, W.Y. DDX3 modulates cell adhesion and motility and cancer cell metastasis via Rac1mediated signaling pathway. Oncogene 2015, 34, 2790-2800. [CrossRef]

34. Nicol, S.M.; Bray, S.E.; Black, H.D.; Lorimore, S.A.; Wright, E.G.; Lane, D.P. The RNA helicase p68 (DDX5) is selectively required for the induction of p53-dependent p21 expression and cell-cycle arrest after DNA damage. Oncogene 2013, 32, 3461-3469. [CrossRef]

35. Hume, S.; Dianov, G.L.; Ramadan, K. A unified model for the G1/S cell cycle transition. Nucleic Acids Res. 2020, 48, 12483-12501. [CrossRef]

36. Lavoie, J.N.; L'Allemain, G.; Brunet, A.; Muller, R.; Pouyssegur, J. Cyclin D1 expression is regulated positively by the p42/p44MAPK and negatively by the p38/HOGMAPK pathway. J. Biol. Chem. 1996, 271, 20608-20616. [CrossRef]

37. Lim, S.; Kaldis, P. Cdks, cyclins and CKIs: Roles beyond cell cycle regulation. Development 2013, 140, $3079-3093$. [CrossRef] [PubMed]

38. Hwang, H.C.; Clurman, B.E. Cyclin E in normal and neoplastic cell cycles. Oncogene 2005, 24, 2776-2786. [CrossRef]

39. Weinberg, R.A. The retinoblastoma protein and cell cycle control. Cell 1995, 81, 323-330. [CrossRef]

40. Stewart, Z.A.; Pietenpol, J.A. p53 Signaling and cell cycle checkpoints. Chem. Res. Toxicol. 2001, 14, 243-263. [CrossRef] [PubMed]

41. Chao, C.H.; Chen, C.M.; Cheng, P.L.; Shih, J.W.; Tsou, A.P.; Lee, Y.H. DDX3, a DEAD box RNA helicase with tumor growthsuppressive property and transcriptional regulation activity of the p21waf1/cip1 promoter, is a candidate tumor suppressor. Cancer Res. 2006, 66, 6579-6588. [CrossRef]

42. Wu, D.W.; Liu, W.S.; Wang, J.; Chen, C.Y.; Cheng, Y.W.; Lee, H. Reduced p21(WAF1/CIP1) via alteration of p53-DDX3 pathway is associated with poor relapse-free survival in early-stage human papillomavirus-associated lung cancer. Clin. Cancer Res. 2011, 17, 1895-1905. [CrossRef]

43. Heerma van Voss, M.R.; Kammers, K.; Vesuna, F.; Brilliant, J.; Bergman, Y.; Tantravedi, S. Global Effects of DDX3 Inhibition on Cell Cycle Regulation Identified by a Combined Phosphoproteomics and Single Cell Tracking Approach. Transl. Oncol. 2018, 11, 755-763. [CrossRef]

44. Tantravedi, S.; Vesuna, F.; Winnard, P.T., Jr.; Martin, A.; Lim, M.; Eberhart, C.G.; Berlinicke, C.; Raabe, E.; van Diest, P.J.; Raman, V. Targeting DDX3 in Medulloblastoma Using the Small Molecule Inhibitor RK-33. Transl. Oncol. 2019, 12, 96-105. [CrossRef] [PubMed]

45. Fu, W.; Verma, D.; Burton, A.; Swaminathan, S. Cellular RNA Helicase DHX9 Interacts with the Essential Epstein-Barr Virus (EBV) Protein SM and Restricts EBV Lytic Replication. J. Virol. 2019, 93, e01244-18. [CrossRef]

46. Xie, M.; Vesuna, F.; Tantravedi, S.; Bol, G.M.; Heerma van Voss, M.R.; Nugent, K.; Malek, R.; Gabrielson, K.; van Diest, P.J.; Tran, P.T.; et al. RK-33 Radiosensitizes Prostate Cancer Cells by Blocking the RNA Helicase DDX3. Cancer Res. 2016, 76, 6340-6350. [CrossRef] [PubMed]

47. Bol, G.M.; Vesuna, F.; Xie, M.; Zeng, J.; Aziz, K.; Gandhi, N.; Levine, A.; Irving, A.; Korz, D.; Tantravedi, S.; et al. Targeting DDX3 with a small molecule inhibitor for lung cancer therapy. EMBO Mol. Med. 2015, 7, 648-669. [CrossRef]

48. Heerma van Voss, M.R.; Vesuna, F.; Trumpi, K.; Brilliant, J.; Berlinicke, C.; de Leng, W.; Kranenburg, O.; Offerhaus, G.J.; Burger, H.; van der Wall, E.; et al. Identification of the DEAD box RNA helicase DDX3 as a therapeutic target in colorectal cancer. Oncotarget 2015, 6, 28312-28326. [CrossRef] [PubMed] 
49. Xie, M.; Vesuna, F.; Botlagunta, M.; Bol, G.M.; Irving, A.; Bergman, Y.; Hosmane, R.S.; Kato, Y.; Winnard, P.T., Jr.; Raman, V. NZ51, a ring-expanded nucleoside analog, inhibits motility and viability of breast cancer cells by targeting the RNA helicase DDX3. Oncotarget 2015, 6, 29901-29913. [CrossRef]

50. Lai, M.C.; Chang, W.C.; Shieh, S.Y.; Tarn, W.Y. DDX3 regulates cell growth through translational control of cyclin E1. Mol. Cell Biol. 2010, 30, 5444-5453. [CrossRef]

51. Wang, J.; Feng, W.; Yuan, Z.; Weber, J.D.; Zhang, Y. DHX33 Interacts with AP-2beta To Regulate Bcl-2 Gene Expression and Promote Cancer Cell Survival. Mol. Cell Biol. 2019, 39, e00017-19. [CrossRef]

52. Fu, J.; Liu, Y.; Wang, X.; Yuan, B.; Zhang, Y. Role of DHX33 in c-Myc-induced cancers. Carcinogenesis 2017, 38, 649-660. [CrossRef]

53. Yuan, B.; Wang, X.; Fan, C.; You, J.; Liu, Y.; Weber, J.D.; Zhong, H.; Zhang, Y. DHX33 Transcriptionally Controls Genes Involved in the Cell Cycle. Mol. Cell Biol. 2016, 36, 2903-2917. [CrossRef] [PubMed]

54. Wang, H.; Yu, J.; Wang, X.; Zhang, Y. The RNA helicase DHX33 is required for cancer cell proliferation in human glioblastoma and confers resistance to PI3K/mTOR inhibition. Cell Signal. 2019, 54, 170-178. [CrossRef]

55. Wang, X.; Feng, W.; Peng, C.; Chen, S.; Ji, H.; Zhong, H.; Ge, W.; Zhang, Y. Targeting RNA helicase DHX33 blocks Ras-driven lung tumorigenesis in vivo. Cancer Sci. 2020, 111, 3564-3575. [CrossRef] [PubMed]

56. Ding, X.; Jia, X.; Wang, C.; Xu, J.; Gao, S.J.; Lu, C. A DHX9-lncRNA-MDM2 interaction regulates cell invasion and angiogenesis of cervical cancer. Cell Death Differ. 2019, 26, 1750-1765. [CrossRef]

57. Yuan, D.; Chen, Y.; Yang, Z.; Li, G.; Wu, M.; Jiang, J.; Li, D.; Yu, Q. SPOP attenuates migration and invasion of choriocarcinoma cells by promoting DHX9 degradation. Am. J. Cancer Res. 2020, 10, 2428-2445. [PubMed]

58. Hong, H.; An, O.; Chan, T.H.M.; Ng, V.H.E.; Kwok, H.S.; Lin, J.S.; Qi, L.; Han, J.; Tay, D.J.T.; Tang, S.J.; et al. Bidirectional regulation of adenosine-to-inosine (A-to-I) RNA editing by DEAH box helicase 9 (DHX9) in cancer. Nucleic Acids Res. 2018, 46, 7953-7969. [CrossRef] [PubMed]

59. Mi, J.; Ray, P.; Liu, J.; Kuan, C.T.; Xu, J.; Hsu, D.; Sullenger, B.A.; White, R.R.; Clary, B.M. In Vivo Selection Against Human Colorectal Cancer Xenografts Identifies an Aptamer That Targets RNA Helicase Protein DHX9. Mol. Ther. Nucleic Acids 2016, 5, e315. [CrossRef] [PubMed]

60. Lee, T.; Di Paola, D.; Malina, A.; Mills, J.R.; Kreps, A.; Grosse, F.; Tang, H.; Zannis-Hadjopoulos, M.; Larsson, O.; Pelletier, J. Suppression of the DHX9 helicase induces premature senescence in human diploid fibroblasts in a p53-dependent manner. J. Biol. Chem. 2014, 289, 22798-22814. [CrossRef]

61. Wang, Y.L.; Liu, J.Y.; Yang, J.E.; Yu, X.M.; Chen, Z.L.; Chen, Y.J.; Kuang, M.; Zhu, Y.; Zhuang, S.M. Lnc-UCID Promotes G1/S Transition and Hepatoma Growth by Preventing DHX9-Mediated CDK6 Down-regulation. Hepatology 2019, 70, $259-275$. [CrossRef] [PubMed]

62. Thacker, U.; Pauzaite, T.; Tollitt, J.; Twardowska, M.; Harrison, C.; Dowle, A.; Coverley, D.; Copeland, N.A. Identification of DHX9 as a cell cycle regulated nucleolar recruitment factor for CIZ1. Sci. Rep. 2020, 10, 18103. [CrossRef] [PubMed]

63. Guenard, F.; Labrie, Y.; Ouellette, G.; Beauparlant, C.J.; Durocher, F.; Inherit BRCAs. Genetic sequence variations of BRCA1interacting genes AURKA, BAP1, BARD1 and DHX9 in French Canadian families with high risk of breast cancer. J. Hum. Genet. 2009, 54, 152-161. [CrossRef] [PubMed]

64. Chen, Z.; Li, Z.; Hu, X.; Xie, F.; Kuang, S.; Zhan, B.; Gao, W.; Chen, X.; Gao, S.; Li, Y.; et al. Structural Basis of Human Helicase DDX21 in RNA Binding, Unwinding, and Antiviral Signal Activation. Adv. Sci. 2020, 7, 2000532. [CrossRef]

65. Zhang, Y.; Baysac, K.C.; Yee, L.F.; Saporita, A.J.; Weber, J.D. Elevated DDX21 regulates c-Jun activity and rRNA processing in human breast cancers. Breast Cancer Res. 2014, 16, 449. [CrossRef]

66. Jung, Y.; Lee, S.; Choi, H.S.; Kim, S.N.; Lee, E.; Shin, Y.; Seo, J.; Kim, B.; Jung, Y.; Kim, W.K.; et al. Clinical validation of colorectal cancer biomarkers identified from bioinformatics analysis of public expression data. Clin. Cancer Res. 2011, 17, 700-709. [CrossRef]

67. Wang, X.; Wu, Z.; Qin, W.; Sun, T.; Lu, S.; Li, Y.; Wang, Y.; Hu, X.; Xu, D.; Wu, Y.; et al. Long non-coding RNA ZFAS1 promotes colorectal cancer tumorigenesis and development through DDX21-POLR1B regulatory axis. Aging 2020, 12, 22656-22687. [CrossRef]

68. Santoriello, C.; Sporrij, A.; Yang, S.; Flynn, R.A.; Henriques, T.; Dorjsuren, B.; Custo Greig, E.; McCall, W.; Stanhope, M.E.; Fazio, M.; et al. RNA helicase DDX21 mediates nucleotide stress responses in neural crest and melanoma cells. Nat. Cell Biol. 2020, 22, 372-379. [CrossRef]

69. Holmstrom, T.H.; Mialon, A.; Kallio, M.; Nymalm, Y.; Mannermaa, L.; Holm, T.; Johansson, H.; Black, E.; Gillespie, D.; Salminen, T.A.; et al. c-Jun supports ribosomal RNA processing and nucleolar localization of RNA helicase DDX21. J. Biol. Chem. 2008, 283, 7046-7053. [CrossRef]

70. Kim, D.S.; Camacho, C.V.; Nagari, A.; Malladi, V.S.; Challa, S.; Kraus, W.L. Activation of PARP-1 by snoRNAs Controls Ribosome Biogenesis and Cell Growth via the RNA Helicase DDX21. Mol. Cell 2019, 75, 1270-1285. [CrossRef]

71. Merrick, W.C. eIF4F: A retrospective. J. Biol. Chem. 2015, 290, 24091-24099.e14. [CrossRef]

72. Raza, F.; Waldron, J.A.; Quesne, J.L. Translational dysregulation in cancer: eIF4A isoforms and sequence determinants of eIF4A dependence. Biochem. Soc. Trans. 2015, 43, 1227-1233. [CrossRef]

73. Rubio, C.A.; Weisburd, B.; Holderfield, M.; Arias, C.; Fang, E.; DeRisi, J.L.; Fanidi, A. Transcriptome-wide characterization of the eIF4A signature highlights plasticity in translation regulation. Genome. Biol. 2014, 15, 476. [CrossRef]

74. Busetto, V.; Barbosa, I.; Basquin, J.; Marquenet, E.; Hocq, R.; Hennion, M.; Paternina, J.A.; Namane, A.; Conti, E.; Bensaude, O.; et al. Structural and functional insights into CWC27/CWC22 heterodimer linking the exon junction complex to spliceosomes. Nucleic Acids Res. 2020, 48, 5670-5683. [CrossRef] 
75. Ryu, I.; Won, Y.S.; Ha, H.; Kim, E.; Park, Y.; Kim, M.K.; Kwon, D.H.; Choe, J.; Song, H.K.; Jung, H.; et al. eIF4A3 Phosphorylation by CDKs Affects NMD during the Cell Cycle. Cell Rep. 2019, 26, 2126-2139.e9. [CrossRef]

76. Han, D.; Gao, X.; Wang, M.; Qiao, Y.; Xu, Y.; Yang, J.; Dong, N.; He, J.; Sun, Q.; Lv, G.; et al. Long noncoding RNA H19 indicates a poor prognosis of colorectal cancer and promotes tumor growth by recruiting and binding to eIF4A3. Oncotarget 2016, 7, 22159-22173. [CrossRef] [PubMed]

77. Liang, W.W.; Cheng, S.C. A novel mechanism for Prp5 function in prespliceosome formation and proofreading the branch site sequence. Genes Dev. 2015, 29, 81-93. [CrossRef] [PubMed]

78. Li, M.; Ma, Y.; Huang, P.; Du, A.; Yang, X.; Zhang, S.; Xing, C.; Liu, F.; Cao, J. Lentiviral DDX46 knockdown inhibits growth and induces apoptosis in human colorectal cancer cells. Gene 2015, 560, 237-244. [CrossRef]

79. Li, B.; Li, Y.M.; He, W.T.; Chen, H.; Zhu, H.W.; Liu, T.; Zhang, J.H.; Song, T.N.; Zhou, Y.L. Knockdown of DDX46 inhibits proliferation and induces apoptosis in esophageal squamous cell carcinoma cells. Oncol. Rep. 2016, 36, 223-230. [CrossRef] [PubMed]

80. Chen, L.; Xu, M.; Zhong, W.; Hu, Y.; Wang, G. Knockdown of DDX46 suppresses the proliferation and invasion of gastric cancer through inactivating Akt/GSK-3beta/beta-catenin pathway. Exp. Cell Res. 2021, 399, 112448. [CrossRef]

81. Jiang, F.; Zhang, D.; Li, G.; Wang, X. Knockdown of DDX46 Inhibits the Invasion and Tumorigenesis in Osteosarcoma Cells. Oncol. Res. 2017, 25, 417-425. [CrossRef] [PubMed]

82. Malumbres, M.; Barbacid, M. Mammalian cyclin-dependent kinases. Trends Biochem. Sci. 2005, 30, 630-641. [CrossRef]

83. Rohaly, G.; Chemnitz, J.; Dehde, S.; Nunez, A.M.; Heukeshoven, J.; Deppert, W.; Dornreiter, I. A novel human p53 isoform is an essential element of the ATR-intra-S phase checkpoint. Cell 2005, 122, 21-32. [CrossRef] [PubMed]

84. Zonta, E.; Bittencourt, D.; Samaan, S.; Germann, S.; Dutertre, M.; Auboeuf, D. The RNA helicase DDX5/p68 is a key factor promoting c-fos expression at different levels from transcription to mRNA export. Nucleic Acids Res. 2013, 41, 554-564. [CrossRef]

85. Srivastava, L.; Lapik, Y.R.; Wang, M.; Pestov, D.G. Mammalian DEAD box protein Ddx51 acts in 3' end maturation of 28S rRNA by promoting the release of U8 snoRNA. Mol. Cell Biol. 2010, 30, 2947-2956. [CrossRef]

86. Bueno, R.; Stawiski, E.W.; Goldstein, L.D.; Durinck, S.; De Rienzo, A.; Modrusan, Z.; Gnad, F.; Nguyen, T.T.; Jaiswal, B.S.; Chirieac, L.R.; et al. Comprehensive genomic analysis of malignant pleural mesothelioma identifies recurrent mutations, gene fusions and splicing alterations. Nat. Genet. 2016, 48, 407-416. [CrossRef] [PubMed]

87. Wang, X.; Liu, H.; Zhao, C.; Li, W.; Xu, H.; Chen, Y. The DEAD-box RNA helicase 51 controls non-small cell lung cancer proliferation by regulating cell cycle progression via multiple pathways. Sci. Rep. 2016, 6, 26108. [CrossRef]

88. Schmidt, M.; Rohe, A.; Platzer, C.; Najjar, A.; Erdmann, F.; Sippl, W. Regulation of G2/M Transition by Inhibition of WEE1 and PKMYT1 Kinases. Molecules 2017, 22, 2045. [CrossRef]

89. Mueller, P.R.; Leise, W.F., 3rd. Measurement of Wee kinase activity. Methods Mol. Biol. 2005, 296, $299-328$.

90. Taylor, W.R.; Stark, G.R. Regulation of the G2/M transition by p53. Oncogene 2001, 20, 1803-1815. [CrossRef]

91. Wang, J.; Liu, J.; Ye, M.; Liu, F.; Wu, S.; Huang, J.; Shi, G. Ddx56 maintains proliferation of mouse embryonic stem cells via ribosome assembly and interaction with the Oct4/Sox2 complex. Stem. Cell Res. Ther. 2020, 11, 314. [CrossRef] [PubMed]

92. Zhu, C.; Zhang, X.; Kourkoumelis, N.; Shen, Y.; Huang, W. Integrated Analysis of DEAD-Box Helicase 56: A Potential Oncogene in Osteosarcoma. Front. Bioeng. Biotechnol. 2020, 8, 588. [CrossRef] [PubMed]

93. Pryszlak, M.; Wiggans, M.; Chen, X.; Jaramillo, J.E.; Burns, S.E.; Richards, L.M.; Pugh, T.J.; Kaplan, D.R.; Huang, X.; Dirks, P.B.; et al. The DEAD-box helicase DDX56 is a conserved stemness regulator in normal and cancer stem cells. Cell Rep. 2021, 34, 108903. [CrossRef]

94. Kouyama, Y.; Masuda, T.; Fujii, A.; Ogawa, Y.; Sato, K.; Tobo, T.; Wakiyama, H.; Yoshikawa, Y.; Noda, M.; Tsuruda, Y.; et al. Oncogenic splicing abnormalities induced by DEAD-Box Helicase 56 amplification in colorectal cancer. Cancer Sc. 2019, 110, 3132-3144. [CrossRef]

95. Mazloomian, A.; Araki, S.; Ohori, M.; El-Naggar, A.M.; Yap, D.; Bashashati, A.; Nakao, S.; Sorensen, P.H.; Nakanishi, A.; Shah, S.; et al. Pharmacological systems analysis defines EIF4A3 functions in cell-cycle and RNA stress granule formation. Commun. Biol. 2019, 2, 165. [CrossRef]

96. Mierzwa, B.; Gerlich, D.W. Cytokinetic abscission: Molecular mechanisms and temporal control. Dev. Cell 2014, 31, 525-538. [CrossRef] [PubMed]

97. Pollard, T.D.; O'Shaughnessy, B. Molecular Mechanism of Cytokinesis. Annu. Rev. Biochem. 2019, 88, 661-689. [CrossRef]

98. Yamazaki, T.; Araki, S.; Ohori, M.; El-Naggar, A.M.; Yap, D.; Bashashati, A.; Nakao, S.; Sorensen, P.H.; Nakanishi, A.; Shah, S.; et al. The closely related RNA helicases, UAP56 and URH49, preferentially form distinct mRNA export machineries and coordinately regulate mitotic progression. Mol. Biol. Cell. 2010, 21, 2953-2965. [CrossRef]

99. Fujita, K.I.; Yamazaki, T.; Harada, K.; Seno, S.; Matsuda, H.; Masuda, S. URH49 exports mRNA by remodeling complex formation and mediating the NXF1-dependent pathway. Biochim. Biophys. Acta Gene Regul. Mech. 2020, 1863, 194480. [CrossRef]

100. Alessi, A.F.; Khivansara, V.; Han, T.; Freeberg, M.A.; Moresco, J.J.; Tu, P.G.; Montoye, E.; Yates, J.R., 3rd; Karp, X.; Kim, J.K. Casein kinase II promotes target silencing by miRISC through direct phosphorylation of the DEAD-box RNA helicase CGH-1. Proc. Natl. Acad. Sci. USA 2015, 112, E7213-E7222. [CrossRef]

101. Taniguchi, K.; Iwatsuki, A.; Sugito, N.; Shinohara, H.; Kuranaga, Y.; Oshikawa, Y.; Tajirika, T.; Futamura, M.; Yoshida, K.; Uchiyama, K.; et al. Oncogene RNA helicase DDX6 promotes the process of c-Myc expression in gastric cancer cells. Mol. Carcinog. 2018, 57, 579-589. [CrossRef] 
102. Audhya, A.; Hyndman, F.; McLeod, I.X.; Maddox, A.S.; Yates, J.R., 3rd; Desai, A.; Oegema, K. A complex containing the Sm protein CAR-1 and the RNA helicase CGH-1 is required for embryonic cytokinesis in Caenorhabditis elegans. J. Cell Biol. 2005, 171, 267-279. [CrossRef]

103. Peters, D.; Radine, C.; Reese, A.; Budach, W.; Sohn, D.; Janicke, R.U. The DEAD-box RNA helicase DDX41 is a novel repressor of p21(WAF1/CIP1) mRNA translation. J. Biol. Chem. 2017, 292, 8331-8341. [CrossRef]

104. Dai, L.; Liu, Y.; Liu, J.; Wen, X.; Xu, Z.; Wang, Z.; Sun, H.; Tang, S.; Maguire, A.R.; Quan, J.; et al. A novel cyclinE/cyclinA-CDK inhibitor targets $\mathrm{p} 27$ (Kip1) degradation, cell cycle progression and cell survival: Implications in cancer therapy. Cancer Lett. 2013, 333, 103-112. [CrossRef]

105. Bali, A.; O’Brien, P.M.; Edwards, L.S.; Sutherland, R.L.; Hacker, N.F.; Henshall, S.M. Cyclin D1, p53, and p21Waf1/Cip1 expression is predictive of poor clinical outcome in serous epithelial ovarian cancer. Clin. Cancer Res. 2004, 10, 5168-5177. [CrossRef] [PubMed]

106. Juan, G.; Ardelt, B.; Li, X.; Mikulski, S.M.; Shogen, K.; Ardelt, W.; Mittelman, A.; Darzynkiewicz, Z. G1 arrest of U937 cells by onconase is associated with suppression of cyclin D3 expression, induction of p16INK4A, p21WAF1/CIP1 and p27KIP and decreased pRb phosphorylation. Leukemia 1998, 12, 1241-1248. [CrossRef] [PubMed]

107. Ando, T.; Kawabe, T.; Ohara, H.; Ducommun, B.; Itoh, M.; Okamoto, T. Involvement of the interaction between p21 and proliferating cell nuclear antigen for the maintenance of G2/M arrest after DNA damage. J. Biol. Chem. 2001, 276, 42971-42977. [CrossRef] [PubMed]

108. Zhang, Z.; Yuan, B.; Bao, M.; Lu, N.; Kim, T.; Liu, Y.J. The helicase DDX41 senses intracellular DNA mediated by the adaptor STING in dendritic cells. Nat. Immunol. 2011, 12, 959-965. [CrossRef]

109. Polprasert, C.; Schulze, I.; Sekeres, M.A.; Makishima, H.; Przychodzen, B.; Hosono, N.; Singh, J.; Padgett, R.A.; Gu, X.; Phillips, J.G.; et al. Inherited and Somatic Defects in DDX41 in Myeloid Neoplasms. Cancer Cell 2015, 27, 658-670. [CrossRef]

110. Weinreb, J.T.; Gupta, V.; Sharvit, E.; Weil, R.; Bowman, T.V. Ddx41 inhibition of DNA damage signaling permits erythroid progenitor expansion in zebrafish. Haematologica 2021. [CrossRef]

111. Iyer, R.S.; Nicol, S.M.; Quinlan, P.R.; Thompson, A.M.; Meek, D.W.; Fuller-Pace, F.V. The RNA helicase/transcriptional coregulator, p68 (DDX5), stimulates expression of oncogenic protein kinase, Polo-like kinase-1 (PLK1), and is associated with elevated PLK1 levels in human breast cancers. Cell Cycle 2014, 13, 1413-1423. [CrossRef] [PubMed]

112. Shin, S.; Rossow, K.L.; Grande, J.P.; Janknecht, R. Involvement of RNA helicases p68 and p72 in colon cancer. Cancer Res. 2007, 67, 7572-7578. [CrossRef]

113. Li, L.X.; Zhou, J.X.; Wang, X.; Zhang, H.; Harris, P.C.; Calvet, J.P.; Li, X. Cross-talk between CDK4/6 and SMYD2 regulates gene transcription, tubulin methylation, and ciliogenesis. Sci. Adv. 2020, 6, eabb3154. [CrossRef]

114. Sithole, N.; Williams, C.A.; Abbink, T.E.M.; Lever, A.M.L. DDX5 potentiates HIV-1 transcription as a co-factor of Tat. Retrovirology 2020, 17, 6. [CrossRef] [PubMed]

115. Kost, G.C.; Yang, M.Y.; Li, L.; Zhang, Y.; Liu, C.Y.; Kim, D.J.; Ahn, C.H.; Lee, Y.B.; Liu, Z.R. A Novel Anti-Cancer Agent, 1-(3,5Dimethoxyphenyl)-4-[(6-Fluoro-2-Methoxyquinoxalin-3-yl)Aminocarbonyl] Piperazine (RX-5902), Interferes With beta-Catenin Function Through Y593 Phospho-p68 RNA Helicase. J. Cell Biochem. 2015, 116, 1595-1601. [CrossRef]

116. Ito, M.; Iwatani, M.; Kamada, Y.; Sogabe, S.; Nakao, S.; Tanaka, T.; Kawamoto, T.; Aparicio, S.; Nakanishi, A.; Imaeda, Y. Discovery of selective ATP-competitive eIF4A3 inhibitors. Bioorg. Med. Chem. 2017, 25, 2200-2209. [CrossRef] [PubMed]

117. Cui, B.C.; Sikirzhytski, V.; Aksenova, M.; Lucius, M.D.; Levon, G.H.; Mack, Z.T.; Pollack, C.; Odhiambo, D.; Broude, E.; Lizarraga, S.B.; et al. Pharmacological inhibition of DEAD-Box RNA Helicase 3 attenuates stress granule assembly. Biochem. Pharmacol. 2020, 182, 114280. [CrossRef] [PubMed]

118. Heerma van Voss, M.R.; Vesuna, F.; Bol, G.M.; Afzal, J.; Tantravedi, S.; Bergman, Y.; Kammers, K.; Lehar, M.; Malek, R.; Ballew, M.; et al. Targeting mitochondrial translation by inhibiting DDX3: A novel radiosensitization strategy for cancer treatment. Oncogene 2018, 37, 63-74. [CrossRef] [PubMed]

119. Steinberger, J.; Shen, L.; Kiniry, S.J.; Naineni, S.K.; Cencic, R.; Amiri, M.; Aboushawareb, S.A.E.; Chu, J.; Maiga, R.I.; Yachnin, B.J.; et al. Identification and characterization of hippuristanol-resistant mutants reveals eIF4A1 dependencies within mRNA 5' leader regions. Nucleic Acids Res. 2020, 48, 9521-9537. [CrossRef]

120. Chu, J.; Pelletier, J. Targeting the eIF4A RNA helicase as an anti-neoplastic approach. Biochim. Biophys. Acta 2015, 1849, 781-791. [CrossRef]

121. Bordeleau, M.E.; Matthews, J.; Wojnar, J.M.; Lindqvist, L.; Novac, O.; Jankowsky, E.; Sonenberg, N.; Northcote, P.; Teesdale-Spittle, P.; Pelletier, J. Stimulation of mammalian translation initiation factor eIF4A activity by a small molecule inhibitor of eukaryotic translation. Proc. Natl. Acad. Sci. USA 2005, 102, 10460-10465. [CrossRef] [PubMed]

122. Bordeleau, M.E.; Cencic, R.; Lindqvist, L.; Oberer, M.; Northcote, P.; Wagner, G.; Pelletier, J. RNA-mediated sequestration of the RNA helicase eIF4A by Pateamine A inhibits translation initiation. Chem. Biol. 2006, 13, 1287-1295. [CrossRef] [PubMed]

123. Sanghvi, V.R.; Mohan, P.; Singh, K.; Cao, L.; Berishaj, M.; Wolfe, A.L.; Schatz, J.H.; Lailler, N.; de Stanchina, E.; Viale, A.; et al. NRF2 Activation Confers Resistance to eIF4A Inhibitors in Cancer Therapy. Cancers 2021, 13, 639. [CrossRef]

124. Capasso, A.; Bagby, S.M.; Dailey, K.L.; Currimjee, N.; Yacob, B.W.; Ionkina, A.; Frank, J.G.; Kim, D.J.; George, C.; Lee, Y.B.; et al. First-in-Class Phosphorylated-p68 Inhibitor RX-5902 Inhibits beta-Catenin Signaling and Demonstrates Antitumor Activity in Triple-Negative Breast Cancer. Mol. Cancer Ther. 2019, 18, 1916-1925. [CrossRef] 
125. Botlagunta, M.; Kollapalli, B.; Kakarla, L.; Gajarla, S.P.; Gade, S.P.; Dadi, C.L.; Penumadu, A.; Javeed, S. In vitro anti-cancer activity of doxorubicin against human RNA helicase, DDX3. Bioinformation 2016, 12, 347-353. [CrossRef]

126. Wilky, B.A.; Kim, C.; McCarty, G.; Montgomery, E.A.; Kammers, K.; DeVine, L.R.; Cole, R.N.; Raman, V.; Loeb, D.M. RNA helicase DDX3: A novel therapeutic target in Ewing sarcoma. Oncogene 2016, 35, 2574-2583. [CrossRef]

127. Tsumuraya, T.; Ishikawa, C.; Machijima, Y.; Nakachi, S.; Senba, M.; Tanaka, J.; Mori, N. Effects of hippuristanol, an inhibitor of eIF4A, on adult T-cell leukemia. Biochem. Pharmacol. 2011, 81, 713-722. [CrossRef]

128. Tsai, B.P.; Jimenez, J.; Lim, S.; Fitzgerald, K.D.; Zhang, M.; Chuah, C.T.; Axelrod, H.; Wilson, L.; Ong, S.T.; Semler, B.L.; et al. A novel Bcr-Abl-mTOR-eIF4A axis regulates IRES-mediated translation of LEF-1. Open Biol. 2014, 4, 140180. [CrossRef] [PubMed]

129. Ishikawa, C.; Tanaka, J.; Katano, H.; Senba, M.; Mori, N. Hippuristanol reduces the viability of primary effusion lymphoma cells both in vitro and in vivo. Mar. Drugs 2013, 11, 3410-3424. [CrossRef]

130. Kuznetsov, G.; Xu, Q.; Rudolph-Owen, L.; Tendyke, K.; Liu, J.; Towle, M.; Zhao, N.; Marsh, J.; Agoulnik, S.; Twine, N.; et al. Potent in vitro and in vivo anticancer activities of des-methyl, des-amino pateamine $\mathrm{A}$, a synthetic analogue of marine natural product pateamine A. Mol. Cancer Ther. 2009, 8, 1250-1260. [CrossRef]

131. Shen, L.; Pelletier, J. Selective targeting of the DEAD-box RNA helicase eukaryotic initiation factor (eIF) 4 A by natural products. Nat. Prod. Rep. 2020, 37, 609-616. [CrossRef]

132. Yang, L.; Lin, C.; Liu, Z.R. P68 RNA helicase mediates PDGF-induced epithelial mesenchymal transition by displacing Axin from beta-catenin. Cell 2006, 127, 139-155. [CrossRef]

133. Tentler, J.J.; Lang, J.; Capasso, A.; Kim, D.J.; Benaim, E.; Lee, Y.B.; Eisen, A.; Bagby, S.M.; Hartman, S.J.; Yacob, B.W.; et al. RX-5902, a novel beta-catenin modulator, potentiates the efficacy of immune checkpoint inhibitors in preclinical models of triple-negative breast Cancer. BMC Cancer 2020, 20, 1063. [CrossRef]

134. Diamond, J.; Eckhardt, G.; Gluck, L.; Gutierrez, M.; Peterson, C.; Pila, R.; Benaim, E. Phase 1 study of RX-5902, a novel orally bioavailable inhibitor of phosphorylated P68, which prevents $\beta$-catenin translocation in advanced solid tumors. Ann. Oncol. 2017, 28, v83. [CrossRef]

135. Hondele, M.; Sachdev, R.; Heinrich, S.; Wang, J.; Vallotton, P.; Fontoura, B.M.A.; Weis, K. DEAD-box ATPases are global regulators of phase-separated organelles. Nature 2019, 573, 144-148. [CrossRef] [PubMed]

136. Zwicker, D.; Decker, M.; Jaensch, S.; Hyman, A.A.; Julicher, F. Centrosomes are autocatalytic droplets of pericentriolar material organized by centrioles. Proc. Natl. Acad. Sci. USA 2014, 111, E2636-E2645. [CrossRef]

137. Jao, L.E.; Akef, A.; Wente, S.R. A role for Gle1, a regulator of DEAD-box RNA helicases, at centrosomes and basal bodies. Mol. Biol. Cell 2017, 28, 120-127. [CrossRef]

138. Iserman, C.; Desroches Altamirano, C.; Jegers, C.; Friedrich, U.; Zarin, T.; Fritsch, A.W.; Mittasch, M.; Domingues, A.; Hersemann, L.; Jahnel, M.; et al. Condensation of Ded1p Promotes a Translational Switch from Housekeeping to Stress Protein Production. Cell 2020, 181, 818-831.e19. [CrossRef] [PubMed]

139. Begovich, K.; Wilhelm, J.E. An In Vitro Assembly System Identifies Roles for RNA Nucleation and ATP in Yeast Stress Granule Formation. Mol. Cell 2020, 79, 991-1007.e4. [CrossRef] [PubMed]

140. Mugler, C.F.; Hondele, M.; Heinrich, S.; Sachdev, R.; Vallotton, P.; Koek, A.Y.; Chan, L.Y.; Weis, K. ATPase activity of the DEAD-box protein Dhh1 controls processing body formation. eLife 2016, 5, e18746. [CrossRef]

141. Sachdev, R.; Hondele, M.; Linsenmeier, M.; Vallotton, P.; Mugler, C.F.; Arosio, P.; Weis, K. Pat1 promotes processing body assembly by enhancing the phase separation of the DEAD-box ATPase Dhh1 and RNA. eLife 2019, 8, e41415. [CrossRef] [PubMed]

142. Di Stefano, B.; Luo, E.C.; Haggerty, C.; Aigner, S.; Charlton, J.; Brumbaugh, J.; Ji, F.; Rabano Jimenez, I.; Clowers, K.J.; Huebner, A.J.; et al. The RNA Helicase DDX6 Controls Cellular Plasticity by Modulating P-Body Homeostasis. Cell Stem. Cell 2019, 25, 622-638.e13.

143. Chen, W.; Hu, Y.; Lang, C.F.; Brown, J.S.; Schwabach, S.; Song, X.; Zhang, Y.; Munro, E.; Bennett, K.; Zhang, D.; et al. The Dynamics of P Granule Liquid Droplets Are Regulated by the Caenorhabditis elegans Germline RNA Helicase GLH-1 via Its ATP Hydrolysis Cycle. Genetics 2020, 215, 421-434. [CrossRef] [PubMed]

144. Voronina, E.; Paix, A.; Seydoux, G. The P granule component PGL-1 promotes the localization and silencing activity of the PUF protein FBF-2 in germline stem cells. Development 2012, 139, 3732-3740. [CrossRef]

145. Marnik, E.A.; Updike, D.L. Membraneless organelles: P granules in Caenorhabditis elegans. Traffic 2019, 20, 373-379. [CrossRef]

146. Klosin, A.; Oltsch, F.; Harmon, T.; Honigmann, A.; Julicher, F.; Hyman, A.A.; Zechner, C. Phase separation provides a mechanism to reduce noise in cells. Science 2020, 367, 464-468. [CrossRef] 